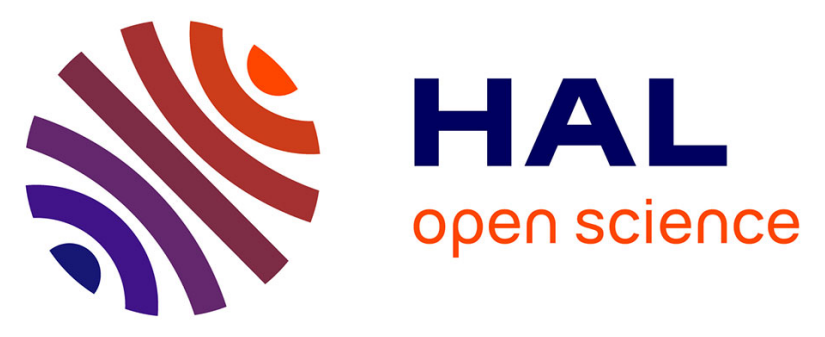

\title{
Mannose-centered aromatic galactoclusters inhibit the biofilm formation of Pseudomonas aeruginosa
}

Caroline Ligeour, Olivier Vidal, Lucie Dupin, Francesca Casoni, Emilie Gillon, Albert Meyer, Sébastien Vidal, Gérard Vergoten, Jean-Marie Lacroix, Eliane Souteyrand, et al.

\section{To cite this version:}

Caroline Ligeour, Olivier Vidal, Lucie Dupin, Francesca Casoni, Emilie Gillon, et al.. Mannosecentered aromatic galactoclusters inhibit the biofilm formation of Pseudomonas aeruginosa. Organic \& Biomolecular Chemistry, 2015, 13 (31), pp.8433-8444. 10.1039/C5OB00948K . hal-01317684

\author{
HAL Id: hal-01317684 \\ https://hal.science/hal-01317684
}

Submitted on 18 Jan 2021

HAL is a multi-disciplinary open access archive for the deposit and dissemination of scientific research documents, whether they are published or not. The documents may come from teaching and research institutions in France or abroad, or from public or private research centers.
L'archive ouverte pluridisciplinaire HAL, est destinée au dépôt et à la diffusion de documents scientifiques de niveau recherche, publiés ou non, émanant des établissements d'enseignement et de recherche français ou étrangers, des laboratoires publics ou privés. 


\title{
Mannose-centered aromatic galactoclusters inhibit the biofilm formation of Pseudomonas aeruginosa
}

\author{
Caroline Ligeour, ${ }^{\text {a }}$ Olivier Vidal, ${ }^{\mathrm{b} *}$ Lucie Dupin, ${ }^{\mathrm{c}}$ Francesca Casoni, ${ }^{\text {a }}$ Emilie Gillon, ${ }^{\mathrm{d}}$ Albert Meyer, ${ }^{\mathrm{a}}$ \\ Sébastien Vidal, ${ }^{\mathrm{e}}$ Gérard Vergoten, ${ }^{\mathrm{b}}$ Jean Marie Lacroix, ${ }^{\mathrm{b}}$ Eliane Souteyrand, ${ }^{\mathrm{c}}$ Anne Imberty, ${ }^{\mathrm{d}}$ Jean- \\ Jacques Vasseur, ${ }^{a}$ Yann Chevolot ${ }^{\mathrm{c} *}$ and François Morvan ${ }^{\mathrm{a} *}$

\begin{abstract}
Pseudomonas aeruginosa (PA) is a major public health care issue due to its ability to develop antibiotic resistance mainly through adhesion and biofilm formation. Therefore, targeting the bacterial molecular arsenal involved into its adhesion and the formation of its biofilm appears as a promising tool against this pathogen. The galactose-binding LecA (or PA-IL) has been described as one of PA virulence factor involved in these processes. Herein, the affinity of three tetravalent mannose-centered galactoclusters toward LecA was evaluated with five different bioanalytical methods: HIA, ELLA, SPR, ITC and DNA-based glycoarray. Inhibitory potential towards biofilm was then assessed for the two glycoclusters with highest affinity towards LecA (Kd values of 157 and $194 \mathrm{nM}$ from ITC measurements). An inhibition of biofilm formation of $40 \%$ was found for these galactoclusters at $10 \mu \mathrm{M}$ concentration. Applications of these macromolecules in anti-bacterial therapy are therefore possible through an anti-adhesive strategy.
\end{abstract}

\section{INTRODUCTION}

The main text of the article should appear here with headings as appropriate. Pseudomonas aeruginosa (PA) is a Gramnegative, motile, opportunistic bacterium responsible for $50 \%$ of mortality for cystic fibrosis patients. ${ }^{1}$ It is one of the most prevalent bacteria involved in nosocomial infection (10-30\%) along with $S$. aureus and $E$. coli. ${ }^{2,3}$ Despite aggressive antibiotic therapy, PA infection in immuno-depressed patients leads to chronic or acute infection leading eventually to death. PA remains a public health issue due to its ability to develop biofilm structure entrapped in host mucins which confer it a particularly high antibiotic resistance. This resistance can be enhanced by a factor of 10 to 1000 compared with the same strain in its planktonic form. ${ }^{4,5}$ Several alternative strategies have been proposed interfering with bacterial attachment to mucins and host tissue, and subsequent biofilm development ${ }^{5}$ such as cell-cell communication, ${ }^{6}$ biofilm dispersion, ${ }^{7,} 8$ bacterial adhesion ${ }^{9}$ and virulence factors. ${ }^{10}$ LecA (or PA-IL) is a tetrameric soluble galactose binding lectin identified as one of

a. Institut des Biomolécules Max Mousseron (IBMM), UMR 5247 CNRS, Université de Montpellier, ENSCM, place Eugène Bataillon, CC1704, 34095 Montpellier Cedex 5, France.E-mail: morvan@univ-montp2.fr

b. Unité de Glycobiologie Structurelle et Fonctionnelle (UGSF), UMR 8576 Université de Lille 1, Cité Scientifique Avenue Mendeleiev, Bat C9, 59655 Villeneuve d'Ascq cedex, France.E-Mail: olivier.vidal@univ-lille1.fr

Université de Lyon, Institut des Nanotechnologies de Lyon UMR CNRS 5270, Ecole Centrale de Lyon, 36 avenue Guy de Collongue, 69134 Ecully, France E-Mail: yann.chevolot@ec-lyon.fr

d. CERMAV, UPR5301, CNRS and Université Grenoble Alpes, 601 rue de la Chimie, BP 53, 38041, Grenoble, France.

e. Institut de Chimie et Biochimie Moléculaires et Supramoléculaires (ICBMS), Laboratoire de Chimie Organique 2 - Glycochimie, UMR 5246, CNRS, Université Claude Bernard Lyon 1, 43 Boulevard du 11 Novembre 1918, 69622 Villeurbanne, France

Electronic Supplementary Information (ESI) available: NMR data. See DOI: $10.1039 / x 0 x \times 00000 x$
PA virulence factor. ${ }^{10}$ LecA acts as an adhesin on the host epithelial cell to facilitate PA adhesion. ${ }^{11,12}$ In the meantime LecA displays several cytotoxic effects ${ }^{13}$ and increases the epithelial barrier permeability to bacterial toxin such as exotoxin A. ${ }^{14}$ Recently, it was demonstrated that LecA promotes cell invasion by PA on host tissue. ${ }^{15}$ Finally, its presence is necessary to promote biofilm formation and allow bacterial maintenance in the lungs. ${ }^{16}$

Inhibition of LecA with synthetic ligands can be achieved with high affinity oligogalactosylated ligands. ${ }^{17-31}$ High binding can be obtained thanks to the so called glycoside cluster effect. ${ }^{32}$, ${ }^{33}$ The design of multivalent ligands targeting LecA has been recently reviewed. ${ }^{34}$ These authors have underlined the importance of the topology, and the structure of the linker between the core of the cluster and the galactosyl residue.

Previous reports have emphasized the benefit of an aromatic aglycon as a mean to further increase the binding of LecA to galactosylated clusters. ${ }^{25,} 31,35,36$ It was shown that phenyl $\beta$-Dgalactoside is 57.1 fold more potent than D-galactose. ${ }^{35} \mathrm{We}$ have recently reported the synthesis and affinity towards LecA of 25 galactocluster-oligonucleotide conjugates exhibiting different linker lengths, rigidities, spatial arrangements and incorporating aromatic aglycons. ${ }^{28}$ For this purpose these conjugates were immobilized on a DNA chip by DNA-Directed Immobilization (DDI) ${ }^{37}$ leading to a glycoarray. ${ }^{38}$ Among the 25 glycoclusters evaluated, the $\mathbf{1}_{\mathrm{DNA}}$ and the $\mathbf{2}_{\mathrm{DNA}}$ (Figure 1 ) bearing four galactose residues displayed a 565 -fold and $844-$ fold increase of potency respectively, in comparison with the monogalactosylated derivative 4 $_{\text {DNA }}$ (Figure 1). In contrast, introduction of the non-aromatic triethyleneglycol aglycon in analogue 3DNA led to a much lower increase of potency ( 6fold) in respect with $\mathbf{4}_{\text {DNA }}$ demonstrating the dramatic benefit of aromatic aglycon on the binding to LecA of our mannosylcentered galactoclusters. 
For biophysical and biological studies, glycoclusters 1-3 (Figure 1 ), corresponding to the galactoclusters without the DNA tag, were synthesized in solution at $\sim 100 \mathrm{mg}$ scale (Scheme 1). Their properties against LecA were evaluated using hemagglutination inhibitory assay (HIA), enzyme linked lectin assay (ELLA), surface plasmon resonance (SPR), isothermal titration microcalorimetry (ITC), and glycoarray. Methyl $\beta$-Dgalactopyranoside (GalOMe) and para-nitrophenyl $\beta$-Dgalactopyranoside (GalOPNP) were used as monomeric reference for comparison.

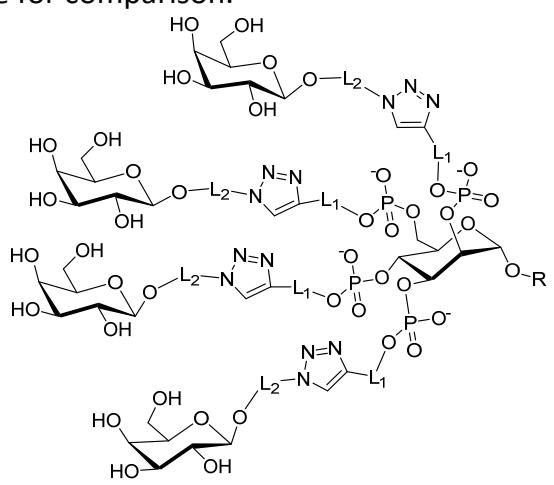

Cy3-DNA-

Суз-DNA = Суз-СTg CCT CTG GGC TCA-O-

Glycocluster

$\mathrm{R}$

$\mathrm{L}_{1}$

$\mathrm{L}_{2}$

$1_{\text {DNA }}$

1

Cy3-DNA

$\mathrm{CH}_{3}$

2 DNA

Cy3-DNA

$\mathrm{CH}_{3}$

Pro

AcNAr

3DNA

3

Cy3-DNA
$\mathrm{CH}_{3}$ $\mathrm{EG}_{2} \mathrm{M} \quad$ AcNAr

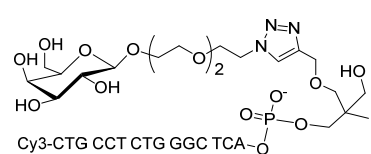

4 DNA

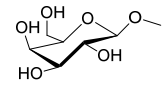

GaloMe

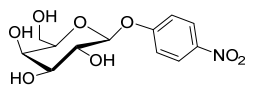

GaIOPNP
Figure 1: Structure of galactoclusters 1-3, 1-4DNA, GalOMe and GalOPNP.

Finally, the anti-biofilm properties of glycoclusters $\mathbf{1}$ and $\mathbf{2}$ were evaluated. For this purpose biofilm of the wild strain PAO1 and the $\triangle$ lecA mutant were grown on abiotic surface in presence or absence of galactoclusters and biofilm development was assessed by fluorescence quantification and confocal scanning laser microscopy (CSLM).

\section{RESULTS AND DISCUSSION}

The glycoclusters 1-3 were synthesized in three steps starting from methyl $\alpha$-D-mannopyranoside $\mathbf{5}$ (Scheme 1). The hydroxyl groups were phosphorylated using an alkyne phosphoramidite $6 a^{39}$ or $6 b^{40}$ activated with benzene thiotetrazole leading to intermediates with phosphitetriester linkages. The phosphitetriesters were then oxidized by means of solidsupported meta-periodate ${ }^{41}$ affording the phosphotriester tetraalkyne mannose platform exhibiting pent-4-ynyl 7a or propargyl diethyleneglycol $\mathbf{7 b}$ groups. Platform 7a was either conjugated by CuAAC with galactosyl azide $8 \mathbf{a}^{21}$ bearing an aromatic linker $\left(L_{2}=A c N P h\right)$ or $\mathbf{8} b^{42}$ bearing a triethylene glycol linker $\left(L_{2}=E G_{3}\right)$ affording galactoclusters $\mathbf{1}$ and $\mathbf{3}$ respectively after ammonia treatment. Platform $\mathbf{7 b}$ was similarly conjugated using $\mathbf{8 a}$ affording galactocluster $\mathbf{2}$ after ammonia treatment.

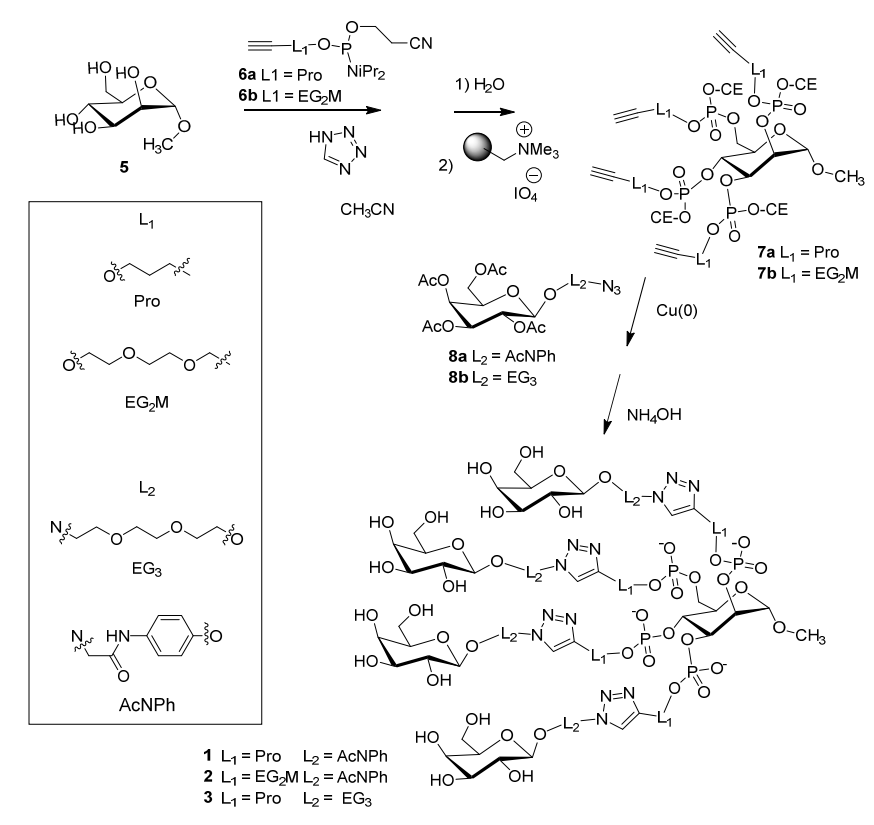

Scheme 1: Synthesis of mannose-centered tetragalactoclusters 1-3.

The binding of LecA to galactoclusters was probed as the ability of the clusters to inhibit the binding of LecA to rabbit erythrocytes (Hemagglutination inhibition assay, HIA) or to surface bound galactosyl modified polyacrylamide either by Surface Plasmon Resonance (SPR) and Enzyme Linked Lectin Assay (ELLA). In HIA experiments, the minimal inhibitory concentration (MIC) is the minimal concentration of galactocluster inhibiting the hemagglutination of rabbit erythrocytes in presence of the lectin. The lower the MIC, the higher is the binding of the galactocluster to the lectin. SPR and ELLA were used to determine $I_{50}$ values as the concentration of galactocluster inhibiting $50 \%$ of LecA binding to the galactosylated surface. The lower the $\mathrm{IC}_{50}$ value as determined by SPR $\left({ }^{\mathrm{SPR}} \mathrm{IC}_{50}\right)$ and ELLA ( $\left.{ }^{\mathrm{ELLA}} \mathrm{IC}_{50}\right)$, the higher is the binding of LecA to the galactocluster. 
GalOMe and GalOPNP were used as reference ligands to determine the impact of the phenyl aglycon on the binding to LecA and the glycoside cluster effect. $\beta_{\mathrm{Me}}$ and $\beta_{\mathrm{PNP}}$ are the relative potencies of the galactoclusters with reference to GalOMe and GalOPNP respectively.

In the HIA assays, the $\beta_{\mathrm{Me}}$ of glycoclusters $\mathbf{1 ,} \mathbf{2}$ and $\mathbf{3}$ are 128, 513 and 4 , respectively (Table 1 ). Hence, the glycoside cluster effect for glycocluster $\mathbf{3}$ remains limited. In contrast, galactoclusters $\mathbf{1}$ and $\mathbf{2}$ exhibit a strong increase of potency with a marked benefit for $\mathbf{2}$ bearing the longest linker between the galactose residue and the mannose core. The calculated potencies in comparison with GalOPNP of 16 and 65 for galactoclusters $\mathbf{1}$ and $\mathbf{2}$ respectively clearly showed a strong glycocluster effect with an increase per residue of 4 and 16 respectively. Therefore, the potency increases are not only related to the presence of the aromatic ring but also to multivalency.

Table 1: Hemagglutination Inhibition Assay (HIA): Inhibition of rabbit erythrocyte agglutination by LecA.

\begin{tabular}{ccccc}
\hline Ligand & Valency & $\begin{array}{c}\text { MIC } \\
(\mathbf{m M})\end{array}$ & $\beta_{\text {Me }}$ & $\beta_{\text {PNP }}$ \\
\hline GalOMe & 1 & 16 & 1.0 & 0.13 \\
GalOPNP & 1 & 2.0 & 8.0 & 1.0 \\
$\mathbf{1}$ & 4 & 0.125 & 128 & 16 \\
$\mathbf{2}$ & 4 & 0.031 & 516 & 65 \\
$\mathbf{3}$ & 4 & 4.0 & 4.0 & 0.5 \\
& & & & \\
\hline
\end{tabular}

The $\mathrm{IC}_{50}$ values of the three glycoclusters and monomers were determined by ELLA and by SPR (Figure 2 and 3, Table 2). ${ }_{\text {ELLA }} \mathrm{C}_{50}$ values demonstrated the higher binding of $\mathbf{1}$ and $\mathbf{2}$ in comparison with GalOMe with $\beta_{\mathrm{Me}}$ of 704 and 3050 respectively, while 3 exhibited a moderate increase ( $\beta_{M e} 6.6$ ). The same trend was observed with ${ }^{S P R}{ }^{I} C_{50}$ values, but with a lower extent ( $\beta_{\mathrm{Me}}$ of 15, 54 and 12 respectively, Table 2 ). In the ${ }^{E L L A} I_{50}$ and ${ }^{\text {SPR }}{ }^{2} C_{50}$ measurements, the $\beta_{\text {PNP }}$ of glycocluster 3 was 1.2 and 1.7 respectively, slightly better than for GalOPNP, (Table 2). This result suggests that potencies of $\mathbf{3}$ is similar to GalOPNP. Both ${ }^{E L L A} I C_{50}$ and ${ }^{\text {SPR } I C_{50}}$ confirmed that glycoclusters $\mathbf{1}$ and $\mathbf{2}$ have improved potencies compared to $\mathbf{3}$ and to the monovalent ligands. The results obtained with HIA, ELLA and SPR confirmed that $\mathbf{2}$ was the best ligand. However, the extent value of these improvements was assay dependent. Indeed, $\beta_{\mathrm{PNP}}$ for galactoclusters 1, 2 and 3 were 127, 550 and 1.2 respectively for ${ }^{{ }^{E L A A} I C_{50}}$ values and 2.0, 7.4 and 1.7 for ${ }^{{ }^{S P R} I C_{50}}$

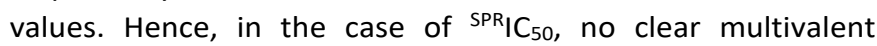
cluster effect could be evidenced. Such discrepancy in the extent of the glycoside cluster effect, according to the nature of the assay, has already been reported in literature. ${ }^{32}$ Nevertheless, the three experiments showed that glycocluster 2 exhibited the best affinity for LecA.

\begin{tabular}{|c|c|c|c|c|c|c|c|}
\hline & & ${ }_{\text {ELLA }} I_{50}$ & & & ${ }^{\mathrm{SPR}_{1} \mathrm{C}_{50}}$ & & \\
\hline Ligand & Valency & $(\mu \mathrm{M})$ & $\beta_{\text {Me }}$ & $\beta_{\mathrm{PNP}}$ & $(\mu \mathrm{M})$ & $\beta_{\text {Me }}$ & $\beta_{\mathrm{PNP}}$ \\
\hline GalOMe & 1 & 183 & 1.0 & 0.2 & 49 & 1.0 & 0.14 \\
\hline GalOPNP & 1 & 33.0 & 5.5 & 1.0 & 6.7 & 7.3 & 1.0 \\
\hline 1 & 4 & 0.26 & 704 & 127 & 3.3 & 15 & 2.0 \\
\hline 2 & 4 & 0.06 & 3050 & 550 & 0.91 & 54 & 7.4 \\
\hline 3 & 4 & 27.6 & 6.6 & 1.2 & 4.0 & 12 & 1.7 \\
\hline
\end{tabular}

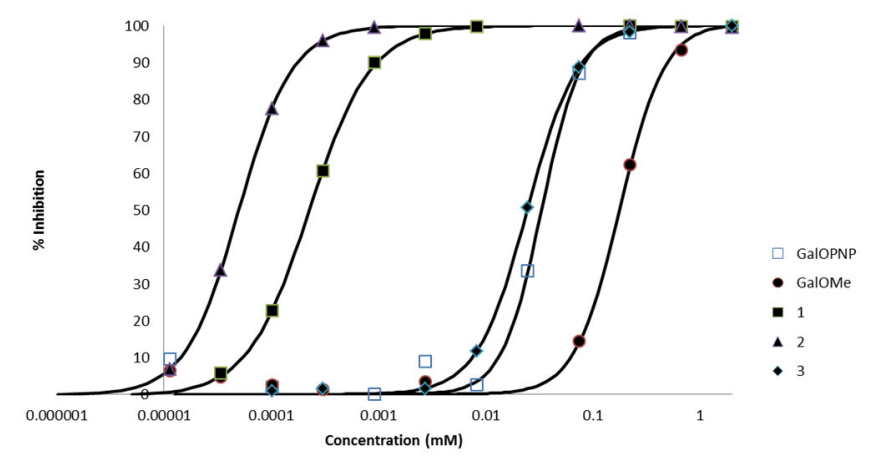

Figure 2. ELLA curves of the galactoclusters 1-3 and monomers GalOMe and GalOPNP.

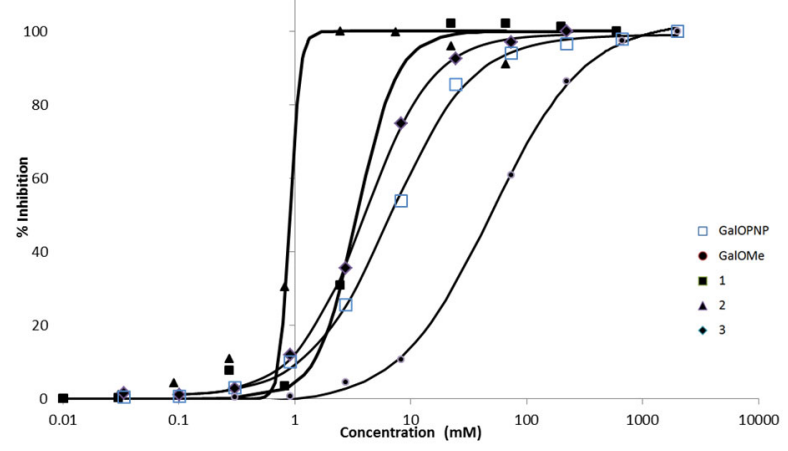

Figure 3. SPR curves of the galactoclusters 1-3 and monomers GalOMe and GalOPNP.

$\mathrm{IC}_{50 \mathrm{Lac}}$ values of the three DNA-tagged glycoclusters $\mathbf{1}_{\mathrm{DNA}}, \mathbf{2}_{\mathrm{DNA}}$ and $3_{\text {DNA }}$ have been previously determined using DDI glycoarray in comparison with $\mathbf{4}_{\text {DNA }}$ used as a reference monovalent ligand (Table 3$).{ }^{28}$ In this case, the $\mathrm{IC}_{50 \text { Lac }}$ value corresponds to the concentration of lactose needed to inhibit $50 \%$ of LecA interaction with surface bound clusters. Thus, in this experiment, the highest the $I_{50}$ value, the better is the binding. Relative potencies of 565, 844 and 5.8 were determined for $\mathbf{1}_{\mathrm{DNA}}, \mathbf{2}_{\mathrm{DNA}}$ and $\mathbf{3}_{\mathrm{DNA}}$, respectively. The ${ }^{\mathrm{ELA}} \mathrm{C}_{50}$ values are in agreement with $\mathrm{IC}_{50 \mathrm{Lac}}$ values determined with the glycoarray assay with the same ranking between the different glycoclusters, but ELLA highlighted the better affinity of glycocluster $\mathbf{2}$ toward LecA. 
Table 3: IC 50 Lac values for DNA-galactoclusters 1-4DNA determined by DDI glycoarray using lactose as inhibitor. ${ }^{28}$

\begin{tabular}{cccc}
\hline Ligand & Valency & IC $_{\text {50Lac }}(\mu \mathrm{M})$ & $\beta 4_{\text {DNA }}$ \\
\hline 1 $_{\text {DNA }}$ & 4 & 2826 & 565 \\
2 $_{\text {DNA }}$ & 4 & 4218 & 844 \\
3 $_{\text {DNA }}$ & 4 & 29 & 5.8 \\
4 $_{\text {DNA }}$ & 1 & 5 & 1 \\
\hline
\end{tabular}

Finally, isothermal titration microcalorimetry (ITC) measurements of the interaction between LecA and the three galactoclusters 1-3 were performed (Figure 4) and compared with data obtained previously with the monovalent GalOMe $\mathrm{G}^{43}$ (Table 4). A ${ }^{{ }^{\mathrm{TTC}}} K_{\mathrm{d}}$ value of $11 \mu \mathrm{M}$ was measured for glycocluster 3, corresponding to a moderate increase of potency of 6.4 fold in respect with GalOMe. The stoichiometry $(n=0.28)$ is in agreement with four galactose residues linked to LecA monomers. Therefore, our results suggested that the entropic cost upon the interaction is not compensated by enthalpic consideration leading to a similar ${ }^{\mathrm{ITC}} K_{\mathrm{d}}$ for both the multivalent $\mathbf{3}$ and the monovalent GalOMe. In contrast, galactoclusters 1 and 2 exhibited a strong increase of potency $\beta_{\mathrm{Me}}$ of 361 and 446-fold respectively. The stoichiometry of 1 and 2 was similar ( $n=0.46$ and 0.52 , respectively), suggesting that two galactose residues were involved simultaneously with LecA monomers. The entropic cost for both interactions is about 3 to 4 times lower than the one observed for glycocluster 3 . Both have similar entropic contributions $(-\mathrm{T} \Delta S)$ similar to the $53 \mathrm{~kJ} / \mathrm{mol}$ observed by Cecioni et al. ${ }^{21}$ with aromatic monovalent ligands. Surprisingly, despite the presence of more flexible linker such as the diethylene glycol arm, the entropic cost with compound $\mathbf{2}$ was lower than for the more rigid aromatic glycocluster $\mathbf{1}$. A possible reason for this may be due to the hydrophobic nature of the aromatic linker of compound $\mathbf{1}$ leading to an increased dehydration entropic cost.

Table 4: ITC data for the interaction between LecA and galactoclusters 1-3.

\begin{tabular}{lccccccc}
\hline Glycoclusters & $\mathbf{n}$ & $\begin{array}{c}-\Delta H \\
(\mathrm{~kJ} / \mathrm{mol})\end{array}$ & $\begin{array}{c}-\mathrm{T} \Delta S \\
(\mathrm{~kJ} / \mathrm{mol})\end{array}$ & $\begin{array}{c}-\Delta G \\
(\mathbf{k J} / \mathrm{mol})\end{array}$ & $\begin{array}{c}{ }^{\mathrm{ITC}} K_{\mathrm{d}} \\
(\mu \mathrm{M})\end{array}$ & $\begin{array}{c}\beta_{\mathrm{Me}}{ }^{\mathrm{a}} \\
{ }^{\mu a \operatorname{aray} K_{\mathrm{d}}} \\
(\mu \mathrm{M})\end{array}$ \\
\hline $\mathbf{1}$ & 0.8 & 39 & 15 & 24 & $70^{\mathrm{a}}$ & 1 & n.a. \\
$\mathbf{2}$ & $0.46 \pm 0.01$ & $81.4 \pm 0.1$ & 43 & 39 & $0.194 \pm 0.007$ & 361 & 0.060 \\
$\mathbf{3}$ & $0.52 \pm 0.01$ & $78 \pm 3$ & 39 & 39 & $0.157 \pm 0.002$ & 446 & 0.039 \\
& $0.28 \pm 0.02$ & $134 \pm 3$ & 105 & 28 & $11 \pm 3$ & 6.4 & 0.395 \\
\hline
\end{tabular}

Relative potency $\left(\beta_{\mathrm{Me}}\right)$ was calculated using the $K_{\mathrm{d}}$ value of $94 \mu \mathrm{M}$ previously reported for GalOMe. ${ }^{43}$ n.a. $=$ not applicable. 

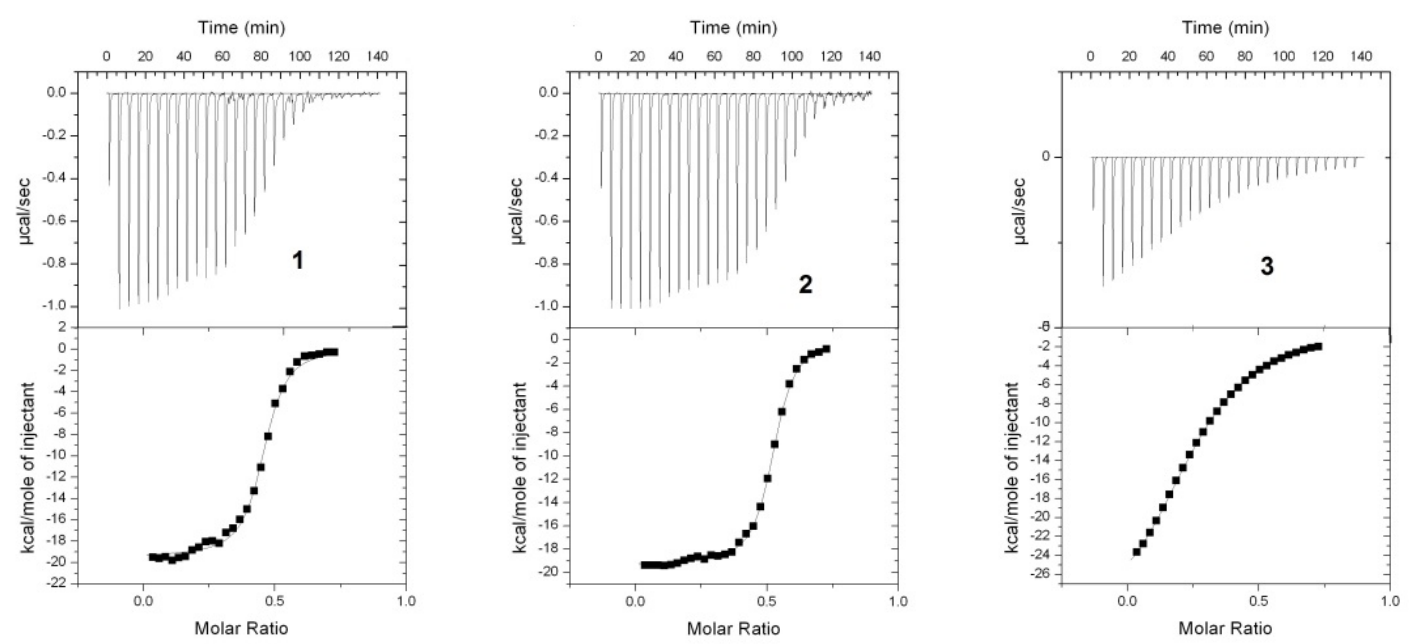

Figure 4: Titration curves obtained from the titration of LecA (from 50 to $270 \mu \mathrm{M}$ depending on the ligand affinity) with glycoclusters $1-3$ ( $175 \mu \mathrm{M}$ ) at $25^{\circ} \mathrm{C}$. Lower panels: the total heat released as a function of total ligand concentration for the titration shown in the upper panels.

In parallel, dissociation constants of the interaction of the glycoclusters $\mathbf{1}_{\text {DNA }}-\mathbf{3}_{\text {DNA }}$ with LecA were measured on microarray using isotherm ${ }^{44}$ leading to a ${ }^{\mu a r r a y} K_{d}$ value of 60,39 and $395 \mathrm{nM}$ respectively. These ${ }^{\mu a r r a y} K_{d}$ values were lower than the ${ }^{\mathrm{TTC}} K_{d}$ values $(194,157$ and $11000 \mathrm{nM})$. This difference between the two assays may be due to the fact that ${ }^{\mu a r r a y} K_{d}$ measurements on microarray are done on a heterogeneous phase system while ITC measurements are done in a homogeneous solution phase system. However, here again, the same ranking in affinity of multivalent ligands for LecA was observed. So the ${ }^{\mu a r r a y} K_{d}$ values determined by glycoarray should be taken as relative data like for SPR or HIA.

Among all the techniques used to quantify the inhibitory potential of the galactomimetics, inhibition of PA biofilm development is the most prevalent. ${ }^{11,16,20,25,45-47}$ Biofilm development is usually quantified (in presence/absence of inhibitors) either by direct observation of fluorescently labeled bacteria within the biofilm structure using Confocal Scanning Laser Microscopy (CSLM) or by quantification of molecules (mostly crystal violet (CV)) associated with the bacteria and reflecting somehow their number within the biofilm structure. On the one hand, using CSLM analysis of acridine orange stained PA biofilm, it was shown that simple molecules as isopropyl- $\beta$-D-thiogalactoside (IPTG) or p-nitrophenyl- $\alpha$-Dgalactoside $(N P G)^{16}$ as well as complex glycopeptides dendrimers ${ }^{20}$ can inhibit at a micromolar range PA Biofilm development. On other hand, classic biofilm quantization by CV-staining allows demonstration that galactosylated glycoclusters presenting either triazine ${ }^{47}$ or calixarenes core structure $^{11}$ can prevent PA biofilm formation at a millimolar concentration. Reymond and coworkers used an original colorimetric assay using indirect $\mathrm{NADH}$ related cell viability to monitor efficiency of glycopeptide dendrimers to inhibit in a micromolar range PA biofilm formation. ${ }^{25}$

In the current work, we focused on a simple and reproducible fluorescence-based technique to monitor biofilm development at the bottom of 96 wells microtitration plates. The technique allows rapid screening of galactoclusters as potential inhibitor on PA biofilm development and thus should be a convenient tool for further identification of efficient inhibitors.

Anti-biofilm potential of the two best galactoclusters $\mathbf{1}$ and $\mathbf{2}$ was then assessed. DAPI labeled biofilm of wild type Pseudomonas aeruginosa strain (PAO1) was compared to the mutant $\triangle$ LecA deficient lecA strain (Figure 5). As expected, lecA mutant biofilm displays a lower fluorescence intensity (Figure 5A and 5B, 25-30\%) compared to PAO1 (100\%) confirming that $\triangle l e c A$ mutant is less prone than the wild type to develop a biofilm. ${ }^{16}$ Analysis of the three-dimensional structure of the biofilm by CSLM (Figure 6) was quantified using COMSTAT1 program (Figure 7) and confirmed that $\Delta / e c A$ mutant was strongly impaired in biofilm formation. Indeed, $\Delta$ lecA biofilm are thinner (average thickness of $0.1 \mathrm{vs} 4.6 \mu \mathrm{m}$ ) than for PAO1 biofilm, contain less biomass (0.05 vs 0.91 $\left.\mu \mathrm{m}^{3} / \mu \mathrm{m}^{2}\right)$ and exhibit a strongly lower surface coverage $(1.2 \%$ for $\triangle l e c A$ vs $51.0 \%$ of surface colonized for PAO1 and

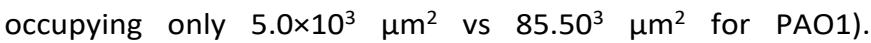
Consequently $\triangle / e c A$ presents a more irregular biofilm structure than the wild type does (roughness coefficient of 1.94 vs 0.69 for PAO1). 

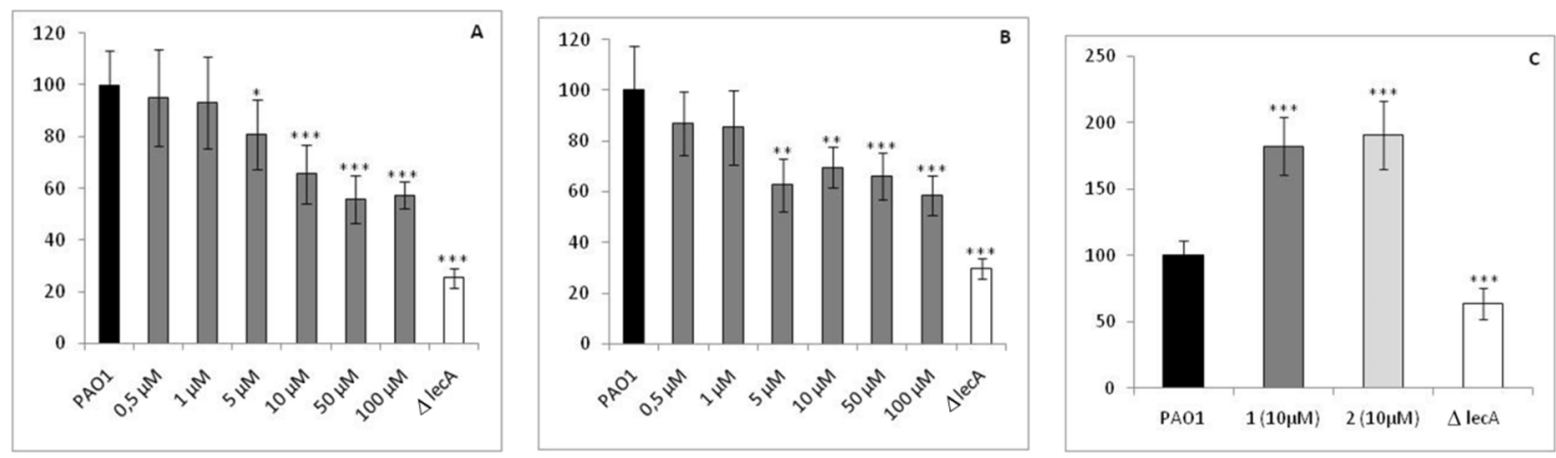

Figure 5. Fluorescence-based quantification of PA biofilm development on permanox chamber slide with or without galactocluster inhibitor, (A) 1; (B) 2. (C) Dispersion of bacteria from $24 \mathrm{~h}$ old PA biofilm by $10 \mu \mathrm{M}$ galactocluster inhibitor, $\mathbf{1}$ and $\mathbf{2}$. Bars represent mean values \pm SEM of $n \geq 8$ independent experiments and biofilm fluorescence is normalized to PAO1 (100\%). The asterisk(s) indicates that the Mann-Whitney calculated $P$ value is less than 0.05 for comparison to PAO1 wild type.* $p<0.05 * * p<0.01, * * * p<0.0001$.

Galactoclusters designed to target LecA are supposed to decrease biofilm formation of PAO1 and should reach biofilm development similar (surface coverage and thickness) of the $\triangle$ lecA mutant. Indeed, concentration higher than $10 \mu \mathrm{M}$ of glycocluster 1 (Figure $5 \mathrm{~A}$ ) and above $5 \mu \mathrm{M}$ for glycocluster 2 (Figure 5B) inhibited biofilm development with an average of $40 \%$. Analysis of the three-dimensional structure of the biofilm developed by PAO1 in the presence of $10 \mu \mathrm{M}$ of glycoclusters 1 and 2 (Figure 6C and 6D) was also performed. Images analysis showed that biofilms of PAO1 grown in presence of each inhibitor contained less biomass $\left(0.62\right.$ and $0.37 \mu^{3} / \mu^{2}$ respectively for 1 and 2 vs $0.91 \mu \mathrm{m}^{3} / \mu \mathrm{m}^{2}$ for PAO1) and were thinner (average thickness of 2.1 and $1.3 \mu \mathrm{m}$ respectively for 1 and 2 vs $4.6 \mu \mathrm{m}$ for PAO1; maximum thickness of 5.3 and 5.8 $\mu \mathrm{m}$ respectively for $\mathbf{1}$ and $\mathbf{2}$ vs $8.2 \mu \mathrm{m}$ for PAO1) than without the glycoclusters (Figure 7). Moreover, they displayed a lower surface coverage $(38 \%$ and $16 \%$ of surface colonized respectively for 1 and 2 vs $51 \%$ for PAO1, occupying $62.2 \times 10^{3}$ $\mu \mathrm{m}^{2}$ and $50.1 \times 10^{3} \mu \mathrm{m}^{2}$ respectively for 1 and 2 vs $85.5 \times 10^{3}$ $\mu \mathrm{m}^{2}$ for PAO1). Together, these results demonstrate the efficiency of both glycoclusters $\mathbf{1}$ and $\mathbf{2}$ to reduce biofilm development of the wild type PAO1 strain. Comparatively, at the same concentration $(10 \mu \mathrm{M})$ galactocluster $\mathbf{2}$ appears more efficient to inhibit biofilm growth compared to compound 1 confirming its better affinity toward LecA observed through HIA, ELLA, SPR, glycoarray and ITC techniques.

Addition of galactoclusters, 1 and $2(10 \mu \mathrm{M})$ to a $24 \mathrm{~h}$ grown biofilm of PAO1 (Figure $5 \mathrm{C}$ ) resulted in an increase of bacterial dispersion compared to the wild type $(* p<0.05)$ as well as the $\triangle l e c A$ mutant strain. This experience demonstrates that
galactocluster/LecA interactions did not only reduce biofilm growth on abiotic surface but also increased the bacterial release from an established biofilm.

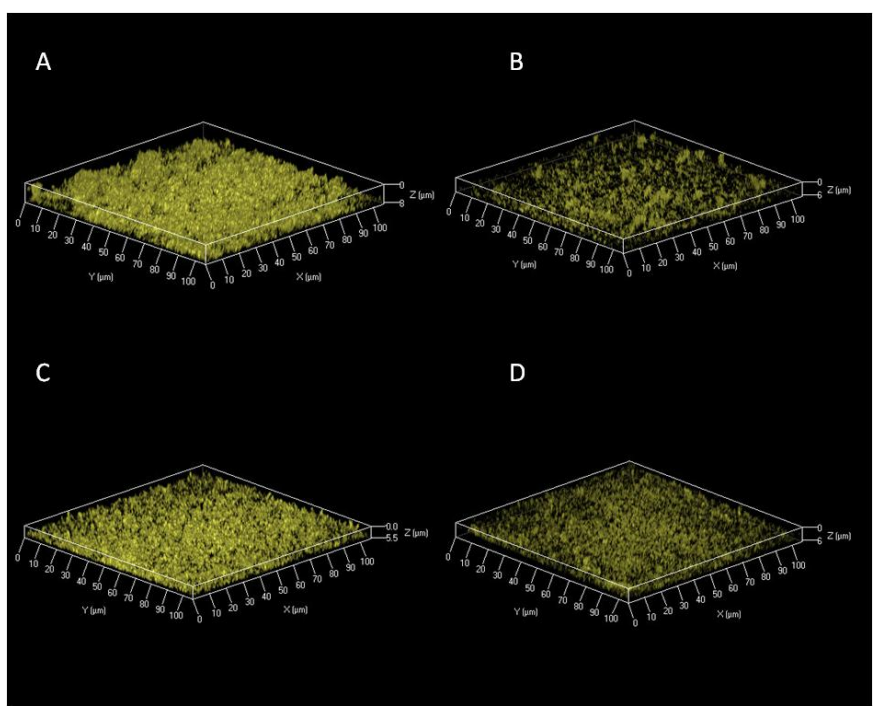

Figure 6. Confocal Laser Scanning Micrographic Images of DAPI-Stained Biofilms of PA developed $24 \mathrm{~h}$ on permanox chamber slides. (A) PAO1, (B) $\triangle / e c A$, (C) PAO1+1 $(10 \mu \mathrm{M})$, (D) PAO1+2 (10 $\mu \mathrm{M})$. 


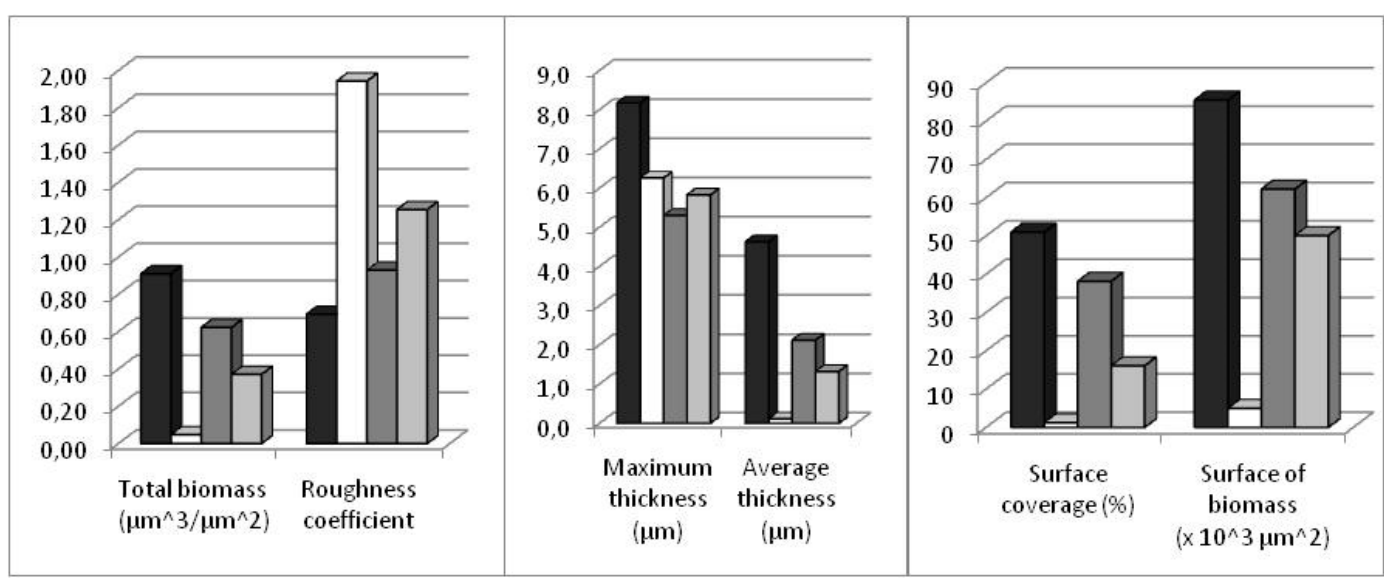

\begin{tabular}{|l|c|c|c|c|c|c|}
\cline { 2 - 6 } \multicolumn{1}{c|}{} & $\begin{array}{c}\text { Total biomass } \\
\left(\mu \mathrm{m}^{3} / \mu \mathrm{m}^{2}\right)\end{array}$ & $\begin{array}{c}\text { Roughness } \\
\text { coefficient }\end{array}$ & $\begin{array}{c}\text { Maximum } \\
\text { thickness }(\mu \mathrm{m})\end{array}$ & $\begin{array}{c}\text { Average } \\
\text { thickness }(\mu \mathrm{m})\end{array}$ & $\begin{array}{c}\text { Surface } \\
\text { coverage } \\
(\%)\end{array}$ & $\begin{array}{c}\text { Surface of } \\
\text { biomass } \\
\left(\times 10^{3} \mu \mathrm{m}^{2}\right)\end{array}$ \\
\hline$\square$ PAO1 & 0.91 & 0.69 & 8.2 & 4.6 & 51.0 & 85.5 \\
\hline$\square$ LlecA & 0.05 & 1.94 & 6.3 & 0.1 & 1.2 & 5.0 \\
\hline PAO1+1 & 0.62 & 0.93 & 5.3 & 2.1 & 38.2 & 62.2 \\
\hline PAO1+2 & 0.37 & 1.25 & 5.8 & 1.3 & 16.1 & 50.1 \\
\hline
\end{tabular}

Figure 7. COMSTAT analysis of the CSLM Images of DAPI-Stained Biofilms of PA developed for $24 \mathrm{~h}$ on permanox chamber slides. ( $\square$ ) PAO1, ( $\square$ ) $\Delta$ lecA, ( $\square$ ) PAO1+1 $(10 \mu \mathrm{M}),(-)$ PAO1+2 $(10 \mu \mathrm{M})$.

Biofilm inhibition studies showed that compound $\mathbf{2}$ displayed a twice higher efficiency than glycocluster 1 (minimum biofilm inhibitory concentration $(\mathrm{MBIC})=5$ vs $10 \mu \mathrm{M})$ and is consequently the best inhibitor evaluated in the present assay. The diverse techniques (HIA, ELLA, SPR, ITC) used in this paper to monitor in vitro lectin/galactoclusters interactions have already indicated that glycocluster $\mathbf{2}$ displayed the best affinity towards LecA. The biofilm inhibition assay was in agreement with the in vitro results and validated that the galactoclusters 1 or $\mathbf{2}$ can inhibit PA biofilm formation. Therefore, there are good candidates for anti-adhesive therapy.

\section{CONCLUSION}

PA colonization of host tissue and biofilm formation provides to the bacteria a selective advantage against antibiotic therapy. LecA is a virulence factor suspected to be involved in PA adhesion. Inhibition of LecA with multivalent galactosylated molecules is forecasted as a mean to inhibit PA-adhesion.

In our strategy, glycoclusters conjugated to a DNA sequence are rapidly synthesized, at a microgram scale, on solid support combining the phosphoramidite chemistry and $\mathrm{Cu}(\mathrm{I})$ catalyzed azide alkyne cycloaddition. ${ }^{28}$ Their screening is performed using a DNA directed immobilization-glycoarray that allows a rapid determination of their binding towards LecA using only minute amount of them. This strategy is suitable to avoid the preparation of a mass of glycoclusters at tens of milligram to select the good one. Only the best ones are synthesized in solution at milligram scale for further evaluations. Herein, we present the binding evaluation by glycoarray of two selected mannose centered galactoclusters to LecA which displayed high affinity to LecA and one of low affinity as control. The selected galactoclusters without the DNA sequence were synthesized in solution at hundreds of milligram scale. Then their binding was determined using five different techniques: HIA, ELLA, SPR, ITC and microarray. The galactoclusters (1 and 2) bearing a phenyl aglycone were found to display a better affinity for LecA than the galactocluster $\mathbf{3}$ with a triethyleneglycol. This result confirmed the known "aromatic benefit" of aromatic galactosides towards LecA binding with $K_{d}$ values below $200 \mathrm{nM}$ found for 1 and 2. ${ }^{25}, 28,31,35,36$ The difference of structure between $\mathbf{1}$ and $\mathbf{2}$ corresponds to a propyl and a diethyleglycol-methylene linking the galactosidephenyl-triazole to the mannose core. This moderate modification is not involved in the interaction with the CRD. However it has a significant effect on the affinity with LecA since 2 was found better than 1 . This result confirms high affinity of a glycocluster to a lectin is a subtle adjustment of its topology with the linkers. The same trend was observed by Pieters who showed that digalactosides differing from only four methylenes displayed difference of $K d$ values of almost four-times ( 28 vs $130 \mathrm{nM}$ ). ${ }^{27}$ The best galactoclusters reported in the literature ${ }^{34}$ display $K_{d}$ values for LecA of $28 \mathrm{nM}^{27}$ and 82 $\mathrm{nM}^{29}$ for digalactosides and $79 \mathrm{nM},{ }^{26} 90 \mathrm{nM},{ }^{21} 100 \mathrm{nM},{ }^{20}$ and $176 \mathrm{nM}^{11}$ for tetragalactosides. The galactoclusters 1 and $\mathbf{2}$ with $K d$ values of $194 \mathrm{nM}$ and $157 \mathrm{nM}$ respectively are in the same range. Finally, galactoclusters $\mathbf{1}$ and $\mathbf{2}$ showed some inhibition of biofilm formation of PA with $40 \%$ of inhibition at $10 \mu \mathrm{M}$ and $5 \mu \mathrm{M}$ concentration respectively where $\Delta$ lecA mutant displayed $70 \%$ of inhibition. The fact that $\triangle$ lecA mutant of PA was still able to form some biofilm confirmed that LecA should not be the only lectin involved in the biofilm formation. Our data confirmed that LecA is a pertinent target to limit the formation of biofilm and demonstrated the use of 
galactocluster to fight PA infections. But it must be pointed out that a combination of other molecules targeting also the second soluble lectin of PA (i.e. LecB) should improve the potential therapeutic effect.

\section{Experimental}

Materials and methods: All reagents were commercial and used without further purification. Acetonitrile was distilled over $\mathrm{CaH}_{2}$. Phosphorylations were performed under an argon atmosphere. NMR spectra were recorded at $293 \mathrm{~K}$ using a 300 $\mathrm{Mhz}, 400 \mathrm{MHz}$ or $600 \mathrm{MHz}$ spectrometer (Bruker). Shifts are referenced relative to deuterated solvent residual peaks. MALDI-TOF mass spectra were recorded on a Voyager mass spectrometer (Perspective Biosystems, Framingham, MA) equipped with a nitrogen laser. High-resolution (HR-ESI-QToF) mass spectra were recorded using a Q-Tof Micromass spectrometer. Thin-layer chromatography (TLC) was carried out on aluminum sheets coated with silica gel 60 F254 (Merck). TLC plates were inspected by UV light $(\lambda=254 \mathrm{~nm})$ and developed by treatment with a mixture of $10 \% \mathrm{H}_{2} \mathrm{SO}_{4}$ in $\mathrm{EtOH} / \mathrm{H}_{2} \mathrm{O}(1: 1 \mathrm{v} / \mathrm{v})$ followed by heating. Reverse phase chromatography was performed with $\mathrm{C}_{18}$ flash column.

\section{Synthesis}

General procedure for phosphorylation: A solution of methyl $\alpha$-D-mannopyranoside $5(50 \mathrm{mg}, 0.26 \mathrm{mmol}, 1 \mathrm{eq})$ in anhydrous $\mathrm{DMF} / \mathrm{CH}_{3} \mathrm{CN}(1: 1.5, \mathrm{v} / \mathrm{v})$ was stirred for $1.5 \mathrm{~h}$ with molecular sieve ( $3 \AA$ ). Then, the alkyne phosphoramidite $6 \mathbf{a}^{39}$ or $6 \mathbf{b}^{28}$ (1.30 mmol, $\left.5 \mathrm{eq}\right)$ was added and a solution of tetrazole $\left(0.4 \mathrm{M}\right.$ in anhydrous $\mathrm{CH}_{3} \mathrm{CN}, 6.4 \mathrm{~mL}, 2.60 \mathrm{mmol}, 10$ eq). The mixture was stirred at $30{ }^{\circ} \mathrm{C}$ for $2 \mathrm{~h}$ and the reaction was quenched with $\mathrm{H}_{2} \mathrm{O}(0.4 \mathrm{~mL})$. After $15 \mathrm{~min}, \mathrm{~A}_{26}\left(\mathrm{IO}_{4}{ }^{-}\right)$resin ${ }^{41}$ $(1.0 \mathrm{~g}, 2.50 \mathrm{mmol}, 9.6 \mathrm{eq})$ was added and the mixture was stirred for $2 \mathrm{~h}$. After filtration of the resin, the DMF was evaporated. The residue was dissolved in dichloromethane (40 $\mathrm{mL})$, the solution was washed with an aqueous saturated solution of $\mathrm{NaHCO}_{3}(60 \mathrm{~mL})$ and brine $(60 \mathrm{~mL})$. The organic layer was dried $\left(\mathrm{Na}_{2} \mathrm{SO}_{4}\right)$, filtered and concentrated to afford the desired tetraalkyne mannose derivatives $\mathbf{7 a - b}$.

\section{1-Methyl-2,3,4,6-tetra-O-pentynylphosphotriester- $\alpha$-D-}

mannopyranoseide 7a: Obtained as a pale yellow oil $(208 \mathrm{mg}$, $81 \%$ ). ${ }^{1} \mathrm{H}$ NMR (300 MHz, $\left.\mathrm{D}_{2} \mathrm{O}\right) \delta 4.98(\mathrm{~d}, J=2.1 \mathrm{~Hz}, 1 \mathrm{H}, \mathrm{H}-1$ ), 4.87-4.57 (m, 3H, H-2, H-5, H-6), 4.37-4.12 (m, $16 \mathrm{H}$, $\left.\mathrm{OCH}_{2} \mathrm{CH}_{2} \mathrm{CN}, \mathrm{POCH}_{2} \mathrm{CH}_{2}\right), 3.94-3.89(\mathrm{~m}, 1 \mathrm{H}, \mathrm{H}-6), 3.45(\mathrm{~s}, 4 \mathrm{H}$, $\left.\mathrm{OCH}_{3}, \mathrm{H}-3\right), 3.40(\mathrm{~m}, 1 \mathrm{H}, \mathrm{H}-4), 2.88-2.78\left(\mathrm{~m}, 8 \mathrm{H}, \mathrm{CH}_{2} \mathrm{CN}\right), 2.39-$ $2.34\left(\mathrm{~m}, 4 \mathrm{H}, \mathrm{CH}_{2} \mathrm{CH}_{2} \mathrm{CCH}\right), 2.08-1.90\left(\mathrm{~m}, 8 \mathrm{H}, \mathrm{POCH}_{2} \mathrm{CH}_{2}\right)$, 1.73$1.64\left(\mathrm{~m}, 4 \mathrm{H}, \mathrm{CH}_{2} \mathrm{CCH}\right){ }^{31} \mathrm{P} \mathrm{NMR}\left(162 \mathrm{MHz}, \mathrm{CDCl}_{3}\right) \delta-1.65$ to $3.01(\mathrm{~m}, \mathrm{P}) .{ }^{13} \mathrm{C}$ NMR $\left(100 \mathrm{MHz}, \mathrm{CDCl}_{3}\right) \delta 115.5$ (CN), $98.3(\mathrm{C}-1)$, $81.5\left(\mathrm{OCH}_{2} \mathrm{CCH}\right), 68.5\left(\mathrm{CH}_{2} \mathrm{CCH}, \mathrm{C}-2, \mathrm{C}-5, \mathrm{C}-6\right), 65.6(\mathrm{C}-3, \mathrm{C}-4)$, $60.9\left(2 \mathrm{~s}, \mathrm{POCH}_{2}\right), 55.7\left(\mathrm{OCH}_{3}\right), 27.7\left(\mathrm{POCH}_{2} \mathrm{CH}_{2}\right), 18.7\left(\mathrm{CH}_{2} \mathrm{CN}\right)$, $13.1\left(\mathrm{CH}_{2} \mathrm{CH}_{2} \mathrm{CCH}\right)$. MALDI-ToF MS average $\mathrm{m} / \mathrm{z}$ calcd for $\mathrm{C}_{39} \mathrm{H}_{55} \mathrm{~N}_{4} \mathrm{O}_{18} \mathrm{P}_{4}[\mathrm{M}+\mathrm{H}]^{+}=991.77$ found 991.86. HR-ESI-QToF MS: isotopic $m / z$ calcd for $\mathrm{C}_{39} \mathrm{H}_{55} \mathrm{~N}_{4} \mathrm{O}_{18} \mathrm{P}_{4}[\mathrm{M}+\mathrm{H}]^{+}=991.2465$ found 991.2462 .

\section{Methyl-2,3,4,6-tetra-O-propargyldiethyleneglycyl}

phosphotriester- $\alpha$-D-mannopyranoseide $7 \mathrm{~b}$ : Obtained as a colourless oil (279 mg, 87\%). ${ }^{1} \mathrm{H}$ NMR (400 MHz, $\left.\mathrm{CDCl}_{3}\right) \delta 4.93$ (d, J=2.4 Hz, 1H, H-1), 4.84-4.79 (m, 1H, H-6), 4.73-4.59 (m, 2H, $\mathrm{H}-2, \mathrm{H}-5), 4.37-4.18\left(\mathrm{~m}, 16 \mathrm{H}, \mathrm{POCH}_{2} \mathrm{CH}_{2} \mathrm{CN}, \mathrm{POCH}_{2} \mathrm{CH}_{2}\right), 4.17-$ $4.12\left(\mathrm{~m}, 8 \mathrm{H}, \mathrm{OCH}_{2} \mathrm{CCH}\right), 3.86-3.80(\mathrm{~m}, 1 \mathrm{H}, \mathrm{H}-6), 3.68(\mathrm{~m}, 8 \mathrm{H}$, $\left.\mathrm{POCH}_{2} \mathrm{CH}_{2}\right), 3.63\left(\mathrm{~s}, 17 \mathrm{H}, \mathrm{OCH}_{2} \mathrm{CH}_{2} \mathrm{O}, \mathrm{H}-3\right), 3.61-3.57(\mathrm{~m}, 1 \mathrm{H}, \mathrm{H}-$ 4), $3.38\left(\mathrm{~s}, 3 \mathrm{H}, \mathrm{OCH}_{3}\right), 2.82-2.74\left(\mathrm{~m}, 8 \mathrm{H}, \mathrm{CH}_{2} \mathrm{CN}\right), 2.46(\mathrm{~m}, 4 \mathrm{H}$, $\left.\mathrm{OCH}_{2} \mathrm{CCH}\right) .{ }^{31} \mathrm{P}$ NMR $\left(162 \mathrm{MHz}, \mathrm{CDCl}_{3}\right) \delta-1.67$ to $-3.11(\mathrm{~m}, \mathrm{P})$. ${ }^{13} \mathrm{C} \mathrm{NMR}\left(100 \mathrm{MHz}, \mathrm{CDCl}_{3}\right) \delta 117.1$ (CN) 98.3 (C-1), 79.6 $\left(\mathrm{OCH}_{2} \mathrm{CCH}\right), 74.9\left(\mathrm{CH}_{2} \mathrm{CCH}, \mathrm{C}-2, \mathrm{C}-5, \mathrm{C}-6\right), 70.2-69.7(2 \mathrm{~m}$, $\left.\mathrm{POCH}_{2} \mathrm{CH}_{2}, \mathrm{C}-3, \mathrm{C}-4\right), 69.1\left(\mathrm{OCH}_{2} \mathrm{CH}_{2} \mathrm{O}\right), 67.8-62.3\left(5 \mathrm{~m}, \mathrm{POCH}_{2}\right)$, $58.3\left(\mathrm{OCH}_{2} \mathrm{CCH}\right), 55.7\left(\mathrm{OCH}_{3}\right), 19.5\left(\mathrm{CH}_{2} \mathrm{CN}\right)$. MALDI-ToF MS average $\mathrm{m} / \mathrm{z}$ calcd for $\mathrm{C}_{47} \mathrm{H}_{71} \mathrm{~N}_{4} \mathrm{O}_{26} \mathrm{P}_{4}[\mathrm{M}+\mathrm{H}]^{+}=1231.97$ found 1231.19. HR-ESI-QToF MS isotopic $m / z$ calcd for $\mathrm{C}_{47} \mathrm{H}_{71} \mathrm{~N}_{4} \mathrm{O}_{26} \mathrm{P}_{4}$ $[\mathrm{M}+\mathrm{H}]^{+}=1231.3297$ found 1231.3307 .

General procedure for 1,3-dipolar cycloaddition and deacetylation of carbohydrate: The alkyne-functionalized compounds $\mathbf{7 a}$ or $\mathbf{7 b}\left(\begin{array}{ll}1.0 & \mathrm{eq}\end{array}\right)$ and the azidotetraacetylgalactose derivatives $8 a^{42}$ or $8 b^{21}$ ( 4 to 4.8 eq) were dissolved in dioxane with triethylammonium acetate buffer (175 $\mu \mathrm{L}, 0.1 \mathrm{M}, \mathrm{pH} 7.7$ ) and nanopowder copper (2 mg). The resulting mixture was stirred overnight at $70{ }^{\circ} \mathrm{C}$. Metallic copper was filtered and the solution was diluted with $\mathrm{CH}_{2} \mathrm{Cl}_{2}$ $(15 \mathrm{~mL})$, and washed with brine $(3 \times 15 \mathrm{~mL})$. The organic layer was dried $\left(\mathrm{Na}_{2} \mathrm{SO}_{4}\right)$, filtered and concentrated to dryness. The resulting product was dissolved in acetone $(5 \mathrm{~mL})$ and concentrated ammonia solution (30\%) was added $(20 \mathrm{~mL})$. The mixture was stirred $1 \mathrm{~h}$ at room temperature. After evaporation, the crude product was dissolved in millia water, and the solution was passed through a column filled with DOWEX-50W X8 resin ( $\mathrm{Na}^{+}$form). After concentration, the residue was purified by $\mathrm{C}_{18}$ flash column chromatography (40 g) $\left(\mathrm{H}_{2} \mathrm{O} / \mathrm{CH}_{3} \mathrm{CN} /\right.$ triethylammonium acetate buffer $0.1 \mathrm{M} \mathrm{pH}$ 7.7, $97: 0: 3$ to $47: 50: 3 \mathrm{v} / \mathrm{v} / \mathrm{v})$. The fractions containing pure glycoclusters 1-3 were combined, evaporated and coevaporated with water several times to eliminate the buffer. Pure glycoclusters 1-3 were dissolved in water $(2 \mathrm{~mL})$ and passed through a column filled with DOWEX-50W X8 resin $\left(\mathrm{Na}^{+}\right.$ form). After evaporation, the residue was dissolved in the minimum amount of water and lyophilized.

Glycocluster 1: Obtained as a pale white solid (141 mg, 64\%) from 7a (100 mg, $0.1 \mathrm{mmol}, 1 \mathrm{eq}), 8 \mathrm{a}$ ( $211 \mathrm{mg}, 0.4 \mathrm{mmol}, 4$ eq), dioxane (2.0 mL). ${ }^{1} \mathrm{H} \mathrm{NMR}\left(300 \mathrm{MHz}, \mathrm{D}_{2} \mathrm{O}\right) \delta 7.82-7.72(4 \mathrm{~s}$, $4 \mathrm{H}, \mathrm{H}$-triaz), 7.34-7.27 (m, 8H, H-ar), 7.04-6.99 (m, 8H, H-ar), 5.30-5.19 (4s, $8 \mathrm{H}, \mathrm{C}(\mathrm{O}) \mathrm{CH}_{2} \mathrm{~N}$-triaz), 4.92-4.89 (m, 5H, H-1 gal, $\mathrm{H}-1$ man), 4.86-4.84 (m, 2H, H-2 man, $\mathrm{H}-3$ man), 4.74-4.72 (m, $2 \mathrm{H}, \mathrm{H}-4$ man, $\mathrm{H}-5$ man), 3.95-3.93 (m, 10H, H-6 man, $\left.\mathrm{OCH}_{2} \mathrm{CH} 2\right)$, 3.85-3.68 (m, 24H, H-2 gal, $\mathrm{H}-3$ gal, H-4 gal, $\mathrm{H}-5$ gal, H-6 gal), $3.30\left(\mathrm{~s}, 3 \mathrm{H}, \mathrm{OCH}_{3}\right), 2.75-2.67\left(\mathrm{~m}, 8 \mathrm{H}, \mathrm{CH}_{2} \mathrm{CH}_{2} \mathrm{C}\right.$-triaz), 1.95-1.81 (m, 8H, $\left.\mathrm{CH}_{2} \mathrm{CH}_{2} \mathrm{CH}_{2}\right)$ ppm. $\left.{ }^{13} \mathrm{C} \mathrm{NMR} \mathrm{(100} \mathrm{MHz,} \mathrm{D}_{2} \mathrm{O}\right) \delta$ $165.3(\mathrm{C}=\mathrm{O}), 153.6\left(\mathrm{C}_{\mathrm{q}}\right.$-ar), 147.2 ( $\mathrm{C}_{\mathrm{q}}$-triaz), 130.8 ( $\mathrm{C}_{\mathrm{q}}$-ar), 124.1 (CH-triaz), 122.5(C-ar), 116.4 (C-ar), 100.4 (C-1 gal), 98.3 (C-1 
man), 74.78, 72.0, 70.0 (3s, 3C, C-2 gal, C-3 gal, C-4 gal, C-5 gal), $67.9\left(\mathrm{OCH}_{2} \mathrm{CH}_{2}\right), 64.7,64.1$ (C-2 man, $\mathrm{C}-3$ man, $\mathrm{C}-4$ man, $\mathrm{C}$ 5 man, $\mathrm{C}-6$ man), 60.1 ( $\mathrm{C}_{6}$ gal), $51.3\left(\mathrm{C}(\mathrm{O}) \mathrm{CH}_{2} \mathrm{~N}\right.$-triaz, $\left.\mathrm{OCH}_{3}\right)$, $29.5\left(\mathrm{CH}_{2} \mathrm{CH}_{2} \mathrm{CH}_{2}\right), 28.8\left(\mathrm{CH}_{2} \mathrm{C}\right.$-triaz$)$. HPLC Rt $=11.25 \mathrm{~min}$. MALDI-ToF MS average $\mathrm{m} / z$ calcd for $\mathrm{C}_{83} \mathrm{H}_{113} \mathrm{~N}_{16} \mathrm{O}_{46} \mathrm{P}_{4}[\mathrm{M}-\mathrm{H}]^{-}=$ 2194.76 found 2194.84 HR-ESI-QToF MS isotopic $\mathrm{m} / \mathrm{z}$ calcd for $\mathrm{C}_{83} \mathrm{H}_{116} \mathrm{~N}_{16} \mathrm{O}_{46} \mathrm{P}_{4}[\mathrm{M}+2 \mathrm{H}]^{++}=1098.3090$ found 1098.3064 .

Glycocluster 2: Obtained as a pale white solid (190 mg, 95\%) from 7b (100 mg, $0.082 \mathrm{mmol}, 1 \mathrm{eq}), 8 a(204 \mathrm{mg}, 0.4 \mathrm{mmol}$, $4.8 \mathrm{eq})$, dioxane $(2.8 \mathrm{~mL}) .{ }^{1} \mathrm{H}$ NMR $\left(600 \mathrm{MHz}, \mathrm{D}_{2} \mathrm{O}\right) \delta 8.19-8.15$ (m, 4H, H-triaz), 7.46-7.44 (m, 8H, H-ar), 7.17-7.15 (m, 8H, Har), 5.45-5.43 (m, $8 \mathrm{H}, \mathrm{C}(\mathrm{O}) \mathrm{CH}_{2} \mathrm{~N}$-triaz), 5.05-5.03 (m, $4 \mathrm{H}, \mathrm{H}-1$ gal), $4.99(\mathrm{~m}, 1 \mathrm{H}, \mathrm{H}-1 \mathrm{man}), 4.74\left(\mathrm{~d}, \mathrm{~J}=2.4 \mathrm{~Hz}, 8 \mathrm{H}, \mathrm{OCH}_{2} \mathrm{C}\right.$-triaz), 4.45-4.32 ( $\mathrm{m}, 3 \mathrm{H}, \mathrm{H}-2$ man, $\mathrm{H}-3$ man, $\mathrm{H}-5$ man), 4.17-4.10 ( $\mathrm{m}$, $6 \mathrm{H}, 3 / 4 \mathrm{POCH}_{2} \mathrm{CH}_{2}$ ), 4.06 (d, J=2.4 Hz, $1 \mathrm{H}, \mathrm{H}-4$ man), 4.04 (d, $J=$ $2.0 \mathrm{~Hz}, 4 \mathrm{H}, \mathrm{H}-4$ gal), 3.89-3.74 (m, 5OH, H-2 gal, $\mathrm{H}-3$ gal, $\mathrm{H}-5$ gal, $\mathrm{H}-6$ gal, $\left.1 / 4 \mathrm{POCH}_{2} \mathrm{CH}_{2}, \mathrm{OCH}_{2} \mathrm{CH}_{2}\right)$, 3.69-3.67 (m, 2H, H-6 man), 3.39 (s, 3H, $\left.\mathrm{OCH}_{3}\right)$ ppm. ${ }^{13} \mathrm{C}$ NMR $\left(150 \mathrm{MHz}, \mathrm{D}_{2} \mathrm{O}\right) \delta 166.1$ $(C=0), 154.4\left(C_{q}-\right.$ ar $), 144.4\left(C_{q}\right.$-triaz), $131.6\left(C_{q}-a r\right), 126.7(C H-$ triaz), 123.4 (C-ar), 117.2 (C-ar), 101.1 (C-1 gal), 98.8 (C-1 man), 75.5, 72.7, 70.7 (3s, 3C, C-2 gal, C-3 gal, C-5 gal), 70.3, 69.7, (2m, 5C, C-2 man, C-3 man, C-4 man, C-5 man, C-6 man), 69.1 (C-4 gal), $68.6\left(\mathrm{OCH}_{2} \mathrm{CH}_{2}\right), 64.9\left(\mathrm{POCH}_{2} \mathrm{CH}_{2}\right), 63.2\left(\mathrm{OCH}_{2} \mathrm{C}\right.$-triaz), 60.9 ( $\mathrm{C}_{6}$ gal), $52.6\left(\mathrm{C}(\mathrm{O}) \mathrm{CH}_{2} \mathrm{~N}\right.$-triaz, $\left.\mathrm{OCH}_{3}\right)$. HPLC Rt $=14.32 \mathrm{~min}$. MALDI-ToF MS average $\mathrm{m} / z$ calcd for $\mathrm{C}_{91} \mathrm{H}_{129} \mathrm{~N}_{16} \mathrm{O}_{54} \mathrm{P}_{4}[\mathrm{M}-\mathrm{H}]^{-}$: 2431.95 found 2432.18. HR-ESI-QToF MS isotopic $\mathrm{m} / \mathrm{z}$ calcd for $\mathrm{C}_{91} \mathrm{H}_{132} \mathrm{~N}_{16} \mathrm{O}_{54} \mathrm{P}_{4}[\mathrm{M}+2 \mathrm{H}]^{++}=1218.3513$ found 1218.3436 .

Glycocluster 3: Obtained as a pale white solid (66 mg, 62\%) from 7a (50 mg, $0.050 \mathrm{mmol}, 1$ eq.), $8 \mathbf{b}$ (101 mg, $0.200 \mathrm{mmol}$, 4 eq.), dioxane (1.5 mL). ${ }^{1} \mathrm{H}$ NMR $\left(600 \mathrm{MHz}, \mathrm{D}_{2} \mathrm{O}\right) \delta 8.00-7.92$ ( $\mathrm{m}, 4 \mathrm{H}, \mathrm{H}$-triaz), $5.01(\mathrm{~m}, 1 \mathrm{H}, \mathrm{H}-1 \mathrm{man}), 4.62-4.64(\mathrm{~m}, 8 \mathrm{H}$, $\mathrm{CH}_{2} \mathrm{~N}$-triaz), 4.48 (dd, $\mathrm{J}=1.8 \mathrm{~Hz}, J=7.8 \mathrm{~Hz}, 3 \mathrm{H}, \mathrm{H}-2$ man, $\mathrm{H}-3$ man, H-5 man), 4.45 (d, J=7.8 Hz, 4H, H-1 gal), 4.14-4.12 (m, $\left.4 \mathrm{H}, 1 / 2 \mathrm{GalOCH}_{2}\right), 3.98\left(\mathrm{~m}, 9 \mathrm{H}, \mathrm{H}-6\right.$ man, $\mathrm{OCH}_{2} \mathrm{CH}_{2} \mathrm{~N}$-triaz), 3.91$3.88\left(\mathrm{~m}, 5 \mathrm{H}, \mathrm{H}-6\right.$ man, H-4 gal), 3.85-3.77 (m, 20H, 1/2 GalOCH $\mathrm{C}_{2}$ $\mathrm{POCH}_{2} \mathrm{CH}_{2}, \mathrm{H}-6$ gal), 3.76-3.67 (m, 32H, H-2 gal, $\mathrm{H}-5$ gal, $\mathrm{OCH}_{2} \mathrm{CH}_{2} \mathrm{O}$ ), 3.61-3.56 (m, 5H, H-3 gal, H-4 man), 3.47 (s, 3H, $\left.\mathrm{OCH}_{3}\right), 2.91-2.78\left(\mathrm{~m}, 8 \mathrm{H}, \mathrm{CH}_{2} \mathrm{CH}_{2} \mathrm{C}\right.$-triaz), $1.97\left(\mathrm{CH}_{2} \mathrm{CH}_{2} \mathrm{C}\right.$-triaz ${ }^{13} \mathrm{C}$ NMR (150 MHz, $\left.\mathrm{D}_{2} \mathrm{O}\right) \delta 103.7$ (C-1 gal, C-1 man), 76.0 $\left(\mathrm{POCH}_{2} \mathrm{CH}_{2}\right.$ ), 75.9, 73.6, 71.6 (3s, 3C, C-2 gal, C-3 gal, C-5 gal), 70.6, 70.5, 70.4, 70.3, 70.2 (C-2 man, C-3 man, C-4 man, C-5 man, C-6 man, $\left.\mathrm{OCH}_{2} \mathrm{CH}_{2} \mathrm{O}\right), 70.0\left(\mathrm{OCH}_{2} \mathrm{CH}_{2} \mathrm{~N}\right.$-triaz), 69.5 (C-4 gal, GalOCH$\left.)_{2}\right), 61.8$ (C-6 gal), $51.0\left(\mathrm{CH}_{2} \mathrm{~N}\right.$-triaz), $44.0\left(\mathrm{CH}_{2} \mathrm{CH}_{2} \mathrm{C}\right.$ triaz), $30.4\left(\mathrm{CH}_{2} \mathrm{CH}_{2} \mathrm{C}\right.$-triaz). MALDI-ToF MS average $\mathrm{m} / \mathrm{z}$ calcd for $\mathrm{C}_{75} \mathrm{H}_{133} \mathrm{~N}_{12} \mathrm{O}_{50} \mathrm{P}_{4}[\mathrm{M}-\mathrm{H}]^{-}=2126.80$ found 2126.54. HR-ESIQToF MS isotopic $m / z$ calcd for $\mathrm{C}_{75} \mathrm{H}_{136} \mathrm{~N}_{12} \mathrm{O}_{50} \mathrm{P}_{4}[\mathrm{M}+2 \mathrm{H}]^{++}=$ 1064.3709 found 1064.3835.

Hemagglutination inhibition assays (HIA): Hemagglutination inhibition assays (HIA) were performed in U-shaped 96-well microtitre plates. Rabbit erythrocytes were purchased from Biomérieux and used without further washing. Erythrocytes were diluted to a $8 \%$ solution in $\mathrm{NaCl}(100 \mathrm{mM})$. Recombinant LecA was produced in Escherichia coli and purified as described previously. ${ }^{48}$ LecA solutions of $3 \mu \mathrm{M}$ were prepared in tris(hydroxymethyl)aminomethane (TRIS-HCl) $20 \mathrm{mM}, \mathrm{NaCl}$
$100 \mathrm{mM}$, and $\mathrm{CaCl}_{2} 100 \mathrm{mM}$. The hemagglutination unit (HU) was first obtained by addition of the $4 \%$ erythrocyte solution $(50 \mu \mathrm{L})$ to aliquots $(50 \mu \mathrm{L})$ of sequential (twice) lectin dilutions. The mixture was incubated at $25{ }^{\circ} \mathrm{C}$ for $30 \mathrm{~min}$. The $\mathrm{HU}$ was measured as the minimum lectin concentration required to observe hemagglutination. For the following lectin-inhibition assays, lectin concentrations of $4 \mathrm{HU}$ were used. For LecA, this concentration was found to be $3 \mu \mathrm{M}$. Subsequent inhibition assays were then carried out by the addition of lectin solution (25 $\mu \mathrm{L}$, at the required concentration) to sequential dilutions $(50 \mu \mathrm{L})$ of glycoclusters, monomer molecules, and controls. These solutions were incubated at $37{ }^{\circ} \mathrm{C}$ for $30 \mathrm{~min}$, then $8 \%$ erythrocyte solution $(25 \mu \mathrm{L})$ was added, followed by an additional incubation at $37^{\circ} \mathrm{C}$ for $1 \mathrm{~h}$. The minimum inhibitory concentration for each molecule was determined for each duplicate.

Determination of lectin concentration by enzyme-linked lectin assay (ELLA): 96-Well microtiter plates (NuncMaxisorb) were coated with $\alpha$-PAA-Gal (PAA=polyacrylamide) for LecA (Lectinity Holding, Inc.): $100 \mu \mathrm{L}$ of $5 \mu \mathrm{g} \cdot \mathrm{mL}^{-1}$ in carbonate buffer, pH 9.6 for $1 \mathrm{~h}$ at $37{ }^{\circ} \mathrm{C}$, then blocking at $37^{\circ} \mathrm{C}$ for $1 \mathrm{~h}$ with $100 \mu \mathrm{L}$ per well of $3 \%(\mathrm{w} / \mathrm{v})$ bovine serum albumin (BSA) in phosphate buffer solution (PBS). Lectin solutions $(75 \mu \mathrm{L})$ were diluted (1:2) starting from $30 \mu \mathrm{g} \cdot \mathrm{mL}^{-1}$. After $1 \mathrm{~h}$ incubation at $37{ }^{\circ} \mathrm{C}$ and three washes with T-PBS (PBS that contained $0.05 \%$ Tween 20), horseradish peroxidase (HRP)streptavidin conjugate (100 $\mu \mathrm{L}$; dilution 2:8000; BoehringerMannheim) was added and left for $1 \mathrm{~h}$ at $37^{\circ} \mathrm{C}$. Coloration was developed by using $100 \mu \mathrm{L}$ per well of $0.05 \%$ phosphate/citrate buffer that contained o-phenylenediamine dihydrochloride $\left(0.4 \mu \mathrm{g} \cdot \mathrm{mL}^{-1}\right)$ and urea hydrogen peroxide $(0.4$ $\mathrm{mg} \cdot \mathrm{mL}^{-1}$ ) (OPD kit, Sigma-Aldrich) for $15 \mathrm{~min}$ and stopped with sulfuric acid (50 $\mu \mathrm{L}, 30 \%)$. Absorbance was then read at 490 $\mathrm{nm}$ using a microtiter plate reader (BioRad 680). The concentration of biotinylated lectins was determined by plotting the relative absorbance versus lectin concentration. The concentration that led to the highest response in the linear area was selected as the standard lectin concentration for the subsequent inhibition experiments. The final concentrations were $0.5 \mu \mathrm{g} \cdot \mathrm{mL}^{-1}$ for LecA.

Isothermal titration microcalorimetry (ITC): Recombinant Iyophilized LecA was dissolved in buffer (100 mM TRIS-HCl, 6 $\mu \mathrm{M} \mathrm{CaCl}, \mathrm{pH}$ 7.5) and degassed. Protein concentration (between 50 and $270 \mu \mathrm{M}$ depending on the ligand affinity) was checked by measurement of optical density by using a theoretical molar extinction coefficient of 28000 . Glycoclusters were dissolved directly into the same buffer, degassed, and placed in the injection syringe (concentration: $175 \mu \mathrm{M}$ ). ITC was performed using a VP-ITC MicroCalorimeter from MicroCal Incorporated. LecA was placed into the $1.4478 \mathrm{~mL}$ sample cell, at $25{ }^{\circ} \mathrm{C}$. Titration was performed with $10 \mu \mathrm{L}$ injections of carbohydrate ligands every $300 \mathrm{~s}$. Data were fitted using the "one-site model" using MicroCal Origin 7 software according to standard procedures. Fitted data yielded the stoichiometry $(n)$, the association constant $\left(K_{\mathrm{a}}\right)$, and the enthalpy of binding $(\Delta H)$. Other thermodynamic parameters (i.e., changes in free 
energy $\Delta G$ and entropy $\Delta S$ ) were calculated from the equation $\Delta G=\Delta H-\mathrm{T} \Delta S=-\mathrm{RT} \ln K_{\mathrm{a}}$ in which $\mathrm{T}$ is the absolute temperature and $\mathrm{R}=8.314 \mathrm{~J} \cdot \mathrm{mol}^{-1} \cdot \mathrm{K}^{-1}$. Two or three independent titrations were performed for each ligand tested.

Surface plasmon resonance (SPR): SPR inhibition experiments were performed using a Biacore 3000 instrument at $25{ }^{\circ} \mathrm{C}$. Measurements were carried out on two channels with two immobilized sugars: $\alpha$-L-fucose (channel 1 ) and $\alpha$-D-galactose (channel 2). Immobilization of sugars was performed at $25^{\circ} \mathrm{C}$ using running buffer (HBS) at $5 \mathrm{~mL} / \mathrm{min}$. Immobilization on each channel (CM5 Chip) was performed independently as follows. First, the channel was activated by injecting a fresh mixture of EDC/NHS (35 $\mu \mathrm{L}, 420 \mathrm{~s}$ ). Then a solution of streptavidin (100 mg/mL in AcONa pH 5 buffer) was injected (50 $\mu \mathrm{L}, 600 \mathrm{~s}$ ). The remaining reactive species were quenched by injecting ethanolamine ( $1 \mathrm{M}, 35 \mu \mathrm{L}, 420 \mathrm{~s})$ into the solution. Finally, a solution of the desired biotinylated-polyacrylamidesugar (Lectinity, $200 \mathrm{mg} / \mathrm{mL}$ ) was coated onto the surface $(50$ $\mu \mathrm{L}, 600 \mathrm{~s})$ through streptavidin-biotin interaction. This procedure led to $804 \mathrm{RU}$ (resonance units) (fucoside) and 796 $\mathrm{RU}$ (galactoside) of immobilized sugars on channels 1 and 2, respectively. Inhibition experiments were performed with the galactosylated channel 2 and plots represent subtracted data (channel 2-channel 1). The running buffer for LecA experiments was HEPES $10 \mathrm{~mm}, \mathrm{NaCl} 150 \mathrm{mM}, \mathrm{CaCl}_{2} 10 \mathrm{mM}$, Tween P20 0.005\%, pH 7.4. Inhibition studies consisted of the injection (150 $\mu \mathrm{L}, 10 \mu \mathrm{L} / \mathrm{min}$, dissociation $120 \mathrm{~s})$ of incubated $(>1 \mathrm{~h}, \mathrm{RT})$ mixtures of LecA $(5 \mu \mathrm{M})$ and various concentrations of inhibitor (two-fold cascade dilutions). For each inhibition assay, LecA $(5 \mu \mathrm{M})$ without inhibitor was injected to observe the full adhesion of the lectin onto the sugar-coated surface ( $0 \%$ inhibition). The $\mathrm{CM} 5$ chip was fully regenerated by successive injections of D-galactose $(2 \times 30 \mu \mathrm{L}, 100 \mathrm{mM}$ in running buffer). Binding was measured as RU over time after blank subtraction, and data were then evaluated using the BIAevaluation Software version 4.1. For $\mathrm{IC}_{50}$ evaluation, the response ( $R_{\text {eq }}$-fitted) was considered to be the amount of lectin bound to the carbohydrate-coated surface at equilibrium in the presence of a defined concentration of inhibitor. Inhibition curves were obtained by plotting the percentage of inhibition against the inhibitor concentration (on a logarithmic scale) by using Origin 7.0 software (OriginLab Corp.), and $\mathrm{IC}_{50}$ values were extracted from sigmoidal fit of the inhibition curve.

Fabrication of Microarray: Microstructured borosilicate glass slides (Nexterion Glass D, Schott Germany) were fabricated using standard photolithography and wet etching process detailed elsewhere. ${ }^{49-51}$ Microstructured slides featured 40 square wells ( $3 \mathrm{~mm}$ width, $60 \pm 1 \mu \mathrm{m}$ depth). The resulting fabricated Slides were functionalized according to the protocol reported in. ${ }^{52-54}$ The slides were washed in freshly prepared piranha rinsed in DI water and dried under dry nitrogen at 150 ${ }^{\circ} \mathrm{C}$ for $2 \mathrm{~h}$. After return to room temperature, tert-butyl-11(dimethylamino)silylundecanoate in dry pentane was allowed to react with glass slide surfaces (RT). After pentane evaporation, the slides were heated at $150{ }^{\circ} \mathrm{C}$ overnight and finally washed in THF and water. The tert-butyl ester function was converted into NHS ester.

Amino modified oligonucleotides were purchased from Eurogentec. Spotting of $0.3 \mathrm{~nL}$ of the various oligonucleotides at $25 \mu \mathrm{M}$ in PBS $10 \mathrm{X}(\mathrm{pH} 8.5)$ at the bottom of each reactor (64 spots per well). The substitution reaction was performed overnight at room temperature in a water saturated atmosphere, and then, water was allowed slowly to evaporate. Washing of the slides was performed with SDS (0.1\%) at $70^{\circ} \mathrm{C}$ for $30 \mathrm{~min}$ and deionized water briefly.

All slides were blocked with BSA 4\% solution in PBS $1 \mathrm{X}(\mathrm{pH} 7.4$, $37{ }^{\circ} \mathrm{C}, 2 \mathrm{~h}$ ) and washed successively in PBS-Tween 20 (0.05\%), PBS $1 \mathrm{X}(\mathrm{pH}$ 7.4) and DI water before being dried by centrifugation.

Lectin labeling: Alexa647 labeling of LecA lectin: LecA lectin was labeled with Alexa Fluor ${ }^{\circledR} 647$ Microscale Protein Labeling Kit (A30009) from Invitrogen. Labeled-lectin concentration and the dye to lectin ratio were estimated by optical density read out with a dual beam spectrometer (Safas) equipped with a microcuvette (Hellma, $5 \mu \mathrm{L}, 1 \mathrm{~mm}$ optical path). The absorbance at $281 \mathrm{~nm}$ and $650 \mathrm{~nm}$ were measured. LecA concentration was estimated to be $11.58 \mu \mathrm{M}$ with a degree of labeling of 0.51 dyes for tetrameric LecA.

"In solution" biological recognition: The methodologies for $K_{\mathrm{d}}$ and $\mathrm{IC}_{50}$ value determination have been previously reported. ${ }^{40 \text {, }}$ 55,56

$K_{d}$ determination by glycoarray: Galactocluster oligonucleotide conjugates $\mathbf{1}_{\text {DNA }}$ or $\mathbf{2}_{\text {DNA }}$ ( $1 \mu \mathrm{M}$ final concentration) were diluted in PBS-0.02\% Tween $_{20}-2 \%$ BSA solution. $\mathrm{CaCl}_{2}(1 \mu \mathrm{g} / \mathrm{mL}$ final concentration) was added. LecA at the desired final concentration was then added. Two $\mu \mathrm{L}$ of each solution (corresponding to the desired LecA concentration) were poured in the corresponding microwells. The slide was incubated $\left(3 \mathrm{~h}, 37^{\circ} \mathrm{C}\right)$ in a water vapor saturated chamber and finally washed in PBS-Tween $20\left(0.02 \%, 5 \mathrm{~min}, 4{ }^{\circ} \mathrm{C}\right)$ and dried. A Microarray scanner, GenePix $4100 A$ software package (Axon Instruments; $\lambda_{\text {ex }} 532 / 635 \mathrm{~nm}$ and $\lambda_{\text {em }} 575 / 670 \mathrm{~nm}$ ) was used for fluorescent imaging of both fluorophore (Cy3 and Alexa 647). The average of the mean fluorescence signal was calculated from eight spots. The resulting Langmuir Isotherms were linearized using Scatchard plot to give the $K_{d}$ values at the ordonnate intercept.

\section{Biofilm Inhibition}

Quantification of biofilm inhibition: PA strains, wild type PAO1 (kindly provided by Pr. Reuben Ramphal, University of Florida Gainsville, FL, USA) and lecA mutant (Two-Allele Library, PW5313, Pseudomonas Transposon Mutant Collection, UW Genome Sciences, Washington, USA) were pre-cultured $16 \mathrm{~h}$ à $37{ }^{\circ} \mathrm{C}$ in LB medium, pelleted and washed in M63-glc prior inoculation of biofilm support with a microbial charge of $10^{6}$ $\mathrm{CFU} / \mathrm{mL}$. Biofilms were grown $24 \mathrm{~h}$ in $\mathrm{M} 63$-glc medium complemented with $10 \mathrm{\mu g} / \mathrm{mL}$ of $4^{\prime}, 6^{\prime}$-diamidino-2- 
phenylindole (DAPI, Sigma) and $\mathrm{CaCl}_{2} 1 \mu \mathrm{M}$ on 96-wells cell culture plates (Greiner Bio-One, Black, FB) and incubated at 37 ${ }^{\circ} \mathrm{C}$ in $\mathrm{CO}_{2}$ incubator Heracell ${ }^{\mathrm{TM}} 150 \mathrm{i}$ (Thermo Scientific). DAPI display no fluorescence in solution and no toxicity towards bacterial cell, it is thus suitable to observe and quantify bacterial growth in biofilm. $\mathrm{CaCl}_{2} 1 \mu \mathrm{M}$ was added to the medium to promote LecA-glycocluster interaction. Prior quantification of fluorescence, biofilms were rinsed 4 times with Dulbecco's phosphate buffered saline (DPBS). Surface colonization in each well was quantified by measurement of DAPI associated fluorescence (ex. $350 \mathrm{~nm} / \mathrm{em} .460 \mathrm{~nm}$ ) using Clariostar fluorescence plate reader (BMG-Labtek).

Three-dimensional organization of the biofilms: The threedimensional organization of the biofilms was analyzed by confocal laser scanning microscopy (CLSM) and imaged using ZEN 2009 Light Edition program. Biofilm were grown 24h in M63-glc medium complemented with $\mathrm{CaCl}_{2} 1 \mu \mathrm{M}$ and 10 $\mu \mathrm{g} / \mathrm{mL}$ of DAPI on Permanox Chamber Slide (Nunc ${ }^{\circledR}$ Lab-Tek $^{\circledR}$ Chamber Slide ${ }^{\mathrm{TM}}$ system) incubated at $37{ }^{\circ} \mathrm{C}$ in $\mathrm{CO}_{2}$ incubator Heracell $^{\mathrm{TM}}$ 150i (Thermo Scientific). Prior analysis, biofilms were rinsed 4 times with Dulbecco's phosphate buffered saline (DPBS), fixed (PFA 4\%) and mounted with Mowiol ${ }^{\circledR}$ 4-88. Biofilms were observed on a Zeiss confocal microscope (LSM780). Biofilms were observed using Zeiss confocal miscroscope (LSM780) with an objective 40x 1.3NA Oil PlanApochromat DIC. The DAPI die was excited with a $405 \mathrm{~nm}$ laser diode and the emission was collected between $410-500 \mathrm{~nm}$ on GaAsP detector.

\section{Structural Analysis of the Biofilm}

Structural analysis was performed using the COMSTAT program. ${ }^{57}$ The image stacks obtained for each CSLM analysis were examined for the following structural features: volume of the biofilm dividedbysubstratum area $\left(\mu \mathrm{m}^{3} / \mu \mathrm{m}^{2}\right)$ indicating total biomass of bacteria; average thickness $(\mu \mathrm{m})$ of the biofilm as well as the maximum thickness $(\mu \mathrm{m})$; roughness coefficient (adimensional), a measure of heterogeneity of the biofilm surface reflecting important variations of biofilm thickness; substratum coverage (\%) and surface colonized area $\left(x 10^{3} \mu \mathrm{m}^{2}\right)$, a reflection of the efficiency with which the bacteria colonizes the surface.

\section{Acknowledgements}

This work was financially supported by ANR-12-BSV5-0020 "GLYCOMIME". Plateforme NanoLyon is acknowledged for its technical support. C. L and F. C. thank University of Montpellier for a research student ship. F.M. is member of Inserm. A.I. acknowledges support from GDR Pseudomonas and Labex ARCANE. S.V. and A.I. are grateful to financial support from the COST Action CM-1102 MultiGlycoNano. The authors thank the Université Claude Bernard Lyon 1 and the CNRS for financial support.

\section{Notes and references}

1. J. B. Lyczak, C. L. Cannon and G. B. Pier, Clin. Microbiol. Rev., 2002, 15, 194-222.

2. F. D. Sottile, T. J. Marrie, D. S. Prough, C. D. Hobgood, D. J. Gower, L. X. Webb, J. W. Costerton and A. G. Gristina, Crit. Care Med., 1986, 14, 265-270.

3. J. L. Vincent, D. J. Bihari, P. M. Suter, H. A. Bruining, J. White, R., M. H. Nicolas-Chanoin, M. Wolff, R. C. Spencer and M. Hemmer, J. Am. Med. Assoc., 1995, 274, 639-644.

4. T. F. C. Mah and G. A. O'Toole, Trends Microbiol., 2001, 9, 34-39.

5. P. S. Stewart and J. W. Costerton, Lancet, 2001, 358, 135138.

6. M. R. Parsek and E. P. Greenberg, Proc. Natl. Acad. Sci. U. S. A., 2000, 97, 8789-8793.

7. D. G. Davies and C. N. H. Marques, J. Bacteriol., 2009, 191, 1393-1403.

8. I. Kolodkin-Gal, S. Cao, L. Chai, T. Boettcher, R. Kolter, J. Clardy and R. Losick, Cell, 2012, 149, 684-692.

9. D. J. Balazs, K. Triandafillu, Y. Chevolot, B. O. Aronsson, H. Harms, P. Descouts and H. J. Mathieu, Surf. Interface Anal., 2003, 35, 301-309.

10. A. Imberty, M. Wimmerova, E. P. Mitchell and N. GilboaGarber, Microb. Infect., 2004, 6, 221-228.

11. A. M. Boukerb, A. Rousset, N. Galanos, J. B. Mear, M. Thepaut, T. Grandjean, E. Gillon, S. Cecioni, C. Abderrahmen, K. Faure, D. Redelberger, E. Kipnis, R. Dessein, S. Havet, B. Darblade, S. E. Matthews, S. de Bentzmann, B. Guery, B. Cournoyer, A. Imberty and S. Vidal, J. Med. Chem., 2014, 57, 10275-10289.

12. C. Chemani, A. Imberty, S. de Bentzmann, M. Pierre, M. Wimmerova, B. P. Guery and K. Faure, Infect. Immun., 2009, 77, 2065-2075.

13. O. Bajolet-Laudinat, S. Girod-de Bentzmann, J. M. Tournier, C. Madoulet, M. C. Plotkowski, C. Chippaux and E. Puchelle, Infect. Immun., 1994, 62, 4481-4487.

14. R. S. Laughlin, M. W. Musch, C. J. Hollbrook, F. M. Rocha, E. B. Chang and J. C. Alverdy, Ann Surg, 2000, 232, 133-142.

15. T. Eierhoff, B. Bastian, R. Thuenauer, J. Madl, A. Audfray, S. Aigal, S. Juillot, G. E. Rydell, S. Mueller, S. de Bentzmann, A. Imberty, C. Fleck and W. Roemer, Proc. Natl. Acad. Sci. U. S. A., 2014, 111, 12895-12900.

16. S. P. Diggle, R. E. Stacey, C. Dodd, M. Camara, P. Williams and K. Winzer, Environ Microbiol, 2006, 8, 1095-1104.

17. S. Cecioni, R. Lalor, B. Blanchard, J. P. Praly, A. Imberty, S. E. Matthews and S. Vidal, Chem. Eur. J., 2009, 15, 1323213240.

18. Y. Chevolot, J. Zhang, A. Meyer, A. Goudot, S. Rouanet, S. Vidal, G. Pourceau, J. P. Cloarec, J. P. Praly, E. Souteyrand, J. J. Vasseur and F. Morvan, Chem. Commun., 2011, 47, 88268828.

19. S. Cecioni, V. Oerthel, J. Iehl, M. Holler, D. Goyard, J. P. Praly, A. Imberty, J. F. Nierengarten and S. Vidal, Chem. Eur. J., 2011, 17, 3252-3261. 

Cacciarini, M. A. Swiderska, C. Nativi, M. Sattler, A. R. Smyth, P. Williams, M. Camara, A. Stocker, T. Darbre and J. L. Reymond, Angew. Chem. Int. Ed., 2011, 50, 10631-10635.

21. S. Cecioni, J. P. Praly, S. E. Matthews, M. Wimmerova, A. Imberty and S. Vidal, Chem. Eur. J., 2012, 18, 6250-6263.

22. M. Reynolds, M. Marradi, A. Imberty, S. Penades and S. Perez, Chem. Eur. J., 2012, 18, 4264-4273.

23. B. Gerland, A. Goudot, G. Pourceau, A. Meyer, S. Vidal, E. Souteyrand, J.-J. Vasseur, Y. Chevolot and F. Morvan, J. Org. Chem., 2012, 77, 7620-7626.

24. F. Pertici and R. J. Pieters, Chem. Commun., 2012, 48, 40084010.

25. R. U. Kadam, D. Garg, J. Schwartz, R. Visini, M. Sattler, A. Stocker, T. Darbre and J. L. Reymond, ACS Chem. Biol., 2013, 8, 1925-1930.

26. M. L. Gening, D. V. Titov, S. Cecioni, A. Audfray, A. G. Gerbst, Y. E. Tsvetkov, V. B. Krylov, A. Imberty, N. E. Nifantiev and S. Vidal, Chem. Eur. J., 2013, 19, 9272-9285.

27. F. Pertici, N. J. de Mol, J. Kemmink and R. J. Pieters, Chem. Eur. J., 2013, 19, 16923-16927.

28. B. Gerland, A. Goudot, C. Ligeour, G. Pourceau, A. Meyer, S. Vidal, T. Gehin, O. Vidal, E. Souteyrand, J. J. Vasseur, Y. Chevolot and F. Morvan, Bioconjugate Chem., 2014, 25, 379-392.

29. A. Novoa, T. Eierhoff, J. Topin, A. Varrot, S. Barluenga, A. Imberty, W. Romer and N. Winssinger, Angew. Chem. Int. Ed., 2014, 53, 8885-8889.

30. C. Ligeour, L. Dupin, A. Marra, G. Vergoten, A. Meyer, A. Dondoni, E. Souteyrand, J. J. Vasseur, Y. Chevolot and F. Morvan, Eur. J. Org. Chem., 2014, 7621-7630.

31. F. Casoni, L. Dupin, G. Vergoten, A. Meyer, C. Ligeour, T. Gehin, O. Vidal, E. Souteyrand, J. J. Vasseur, Y. Chevolot and F. Morvan, Org. Biomol. Chem., 2014, 12, 9166-9179.

32. J. J. Lundquist and E. J. Toone, Chem. Rev., 2002, 102, 555578.

33. M. Mammen, S.-K. Choi and G. M. Whitesides, Angew. Chem., Int. Ed. Engl., 1998, 37, 2754-2794.

34. S. Cecioni, A. Imberty and S. Vidal, Chem. Rev., 2015, 115, 525-561.

35. N. Garber, U. Guempel, A. Belz, N. Gilboagarber and R. J. Doyle, Biochim. Biophys. Acta, 1992, 1116, 331-333.

36. J. Rodrigue, G. Ganne, B. Blanchard, C. Saucier, D. Giguere, T. C. Shiao, A. Varrot, A. Imberty and R. Roy, Org. Biomol. Chem., 2013, 11, 6906-6918.

37. R. Wacker and C. M. Niemeyer, ChemBioChem, 2004, 5, 453-459.

38. Y. Chevolot, C. Bouillon, S. Vidal, F. Morvan, A. Meyer, J. P. Cloarec, A. Jochum, J. P. Praly, J. J. Vasseur and E. Souteyrand, Angew. Chem. Int. Ed., 2007, 46, 2398-2402.

39. G. Pourceau, A. Meyer, J. J. Vasseur and F. Morvan, J. Org. Chem., 2009, 74, 6837-6842.
40. B. Gerland, A. Goudot, G. Pourceau, A. Meyer, V. Dugas, S. Cecioni, S. Vidal, E. Souteyrand, J. J. Vasseur, Y. Chevolot and F. Morvan, Bioconjugate Chem., 2012, 23, 1534-1547.

41. C. Dueymes, A. Schonberger, I. Adamo, A. E. Navarro, A. Meyer, M. Lange, J. L. Imbach, F. Link, F. Morvan and J. J. Vasseur, Org. Lett., 2005, 7, 3485-3488.

42. C. Bouillon, A. Meyer, S. Vidal, A. Jochum, Y. Chevolot, J. P. Cloarec, J. P. Praly, J. J. Vasseur and F. Morvan, J. Org. Chem., 2006, 71, 4700-4702.

43. S. Cecioni, S. Faure, U. Darbost, I. Bonnamour, H. ParrotLopez, O. Roy, C. Taillefumier, M. Wimmerova, J. P. Praly, A. Imberty and S. Vidal, Chem. Eur. J., 2011, 17, 2146-2159.

44. A. Goudot, G. Pourceau, A. Meyer, T. Gehin, S. Vidal, J. J. Vasseur, F. Morvan, E. Souteyrand and Y. Chevolot, Biosens. Bioelectron., 2013, 40 153-160.

45. K. D. Zinger-Yosovich, D. lluz, D. Sudakevitz and N. GilboaGarber, J. Dairy Sci., 2010, 93, 473-482.

46. A. Grishin, A. S. Karyagina, I. G. Tiganova, O. Y. Dobrynina, T. N. Bolshakova, I. S. Boksha, N. V. Alexeyeva, T. V. Stepanova, V. G. Lunin, A. G. Chuchalin and A. L. Ginzburg, Int J Antimicrob Ag, 2013, 42, 471-472.

47. M. Smadhi, S. de Bentzmann, A. Imberty, M. Gingras, R. Abderrahim and P. G. Gopkjian, Beilstein J Org Chem, 2014, 10, 1981-1990.

48. B. Blanchard, A. Nurisso, E. Hollville, C. Tetaud, J. Wiels, M. Pokorna, M. Wimmerova, A. Varrot and A. Imberty, J. Mol. Biol., 2008, 383, 837-853.

49. R. Mazurczyk, G. E. Khoury, V. Dugas, B. Hannes, E. Laurenceau, M. Cabrera, S. Krawczyk, E. Souteyrand, J. P. Cloarec and Y. Chevolot, Sens. Actuators, B, 2008, 128, 552 559.

50. J. Vieillard, R. Mazurczyk, C. Morin, B. Hannes, Y. Chevolot, DesbèneP-L. and S. Krawczyk, J. Chromatogr. B, 2007, 845, 218-225.

51. J. Vieillard, R. Mazurczyk, L. L. Boum, A. Bouchard, Y. Chevolot, P. Cremillieu, B. Hannes and S. Krawczyk, Microelectron. Eng., 2008, 85, 465-469.

52. V. Dugas and Y. Chevalier, J. Colloid Interface Sci., 2003, 264, 354-361.

53. V. Dugas, G. Depret, B. Chevalier, X. Nesme and E. Souteyrand, Sens. Actuators, B, 2004, 101, 112-121.

54. M. Phaner-Goutorbe, V. Dugas, Y. Chevolot and E. Souteyrand, Mater. Sci. Eng., C, 2011, 31, 384-390.

55. J. Zhang, G. Pourceau, A. Meyer, S. Vidal, J. P. Praly, E. Souteyrand, J. J. Vasseur, F. Morvan and Y. Chevolot, Chem. Commun., 2009, 6795-6797.

56. J. Zhang, G. Pourceau, A. Meyer, S. Vidal, J.-P. Praly, E. Souteyrand, J.-J. Vasseur, F. Morvan and Y. Chevolot, Biosens. Bioelectron., 2009, 24, 2515-2521.

57. A. Heydorn, A. T. Nielsen, M. Hentzer, C. Sternberg, M. Givskov, B. K. Ersboll and S. Molin, Microbiol-Uk, 2000, 146, 2395-2407. 